\title{
Adaptive Immune Responses in Hepatitis A Virus and Hepatitis E Virus Infections
}

\author{
Christopher M. Walker \\ Center for Vaccines and Immunity, The Research Institute at Nationwide Children's, Columbus, Ohio 43004 \\ Correspondence: christopher.walker@nationwidechildrens.org
}

Both hepatitis A virus (HAV) and hepatitis E virus (HEV) cause self-limited infections in humans that are preventable by vaccination. Progress in characterizing adaptive immune responses against these enteric hepatitis viruses, and how they contribute to resolution of infection or liver injury, has therefore remained largely frozen for the past two decades. How HAV and HEV infections are so effectively controlled by B- and T-cell immunity, and why they do not have the same propensity to persist as HBV and HCV infections, cannot yet be adequately explained. The objective of this review is to summarize our understanding of the relationship between patterns of virus replication, adaptive immune responses, and acute liver injury in HAV and HEV infections. Gaps in knowledge, and recent studies that challenge long-held concepts of how antibodies and T cells contribute to control and pathogenesis of HAV and HEV infections, are highlighted.

$\mathrm{H}$ epatitis A virus (HAV) and hepatitis E virus (HEV) cause self-limited infections that are often clinically silent. Safe and relatively inexpensive vaccines prevent infection with both viruses through induction of antibodies that provide apparent sterilizing immunity. HEV vaccines are not yet commercially available in most countries, but HAV incidence has declined dramatically in regions of the world where that vaccine has been widely deployed. Despite these generally positive circumstances, there is still an imperative to improve our poor understanding of immunity and pathogenesis in HAV and $\mathrm{HEV}$ infections. Liver disease has long been suspected of having an immunopathogenic origin in HAV and HEV infection, but host responses causing hepatocellular injury remain undefined. There is still a need to address these gaps in knowledge. Sporadic or epidemic outbreaks of HAV still occur in many regions of the world and liver disease is sometimes severe, especially among adults who often no longer acquire protective immunity during childhood because of the decreased prevalence of the virus. The scope of liver disease caused by HEV is broad and poorly understood from a mechanistic standpoint. HEV genotype (gt)1 and gt 2 infections are transmitted primarily by contaminated water and household contact. The outcome of infection is sometimes catastrophic, especially for women who are infected during the late stages of pregnancy. HEV gt 3 and gt 4 infections are predominately zoonotic and much more likely to be clinically inapparent than those caused by gt1 and gt 2 viruses. These genotypes have not yet been associated with adverse outcomes in preg-

Editors: Stanley M. Lemon and Christopher Walker

Additional Perspectives on Enteric Hepatitis Viruses available at www.perspectivesinmedicine.org

Copyright (C) 2019 Cold Spring Harbor Laboratory Press; all rights reserved; doi: 10.1101/cshperspect.a033472

Cite this article as Cold Spring Harb Perspect Med 2019;9:a033472 
nancy. Importantly, however, the gt3 and possibly gt4 viruses may be unique in their ability to cause persistent infections and rapidly progressive liver disease in humans with compromised immunity. Insight into the nature of HEV immune responses that cause disease and prevent persistent infection is limited.

The objective of this review is to describe characteristics of B- and T-cell immunity elicited by the enteric hepatitis viruses, their contribution to control of acute infection and liver damage, and mechanisms of viral evasion. Significant gaps in knowledge about the role of adaptive immune responses in the outcome of $\mathrm{HAV}$ and HEV infections remain and are highlighted.

\section{HUMORAL IMMUNE RESPONSES}

Humans are susceptible to infection with viruses that group into three HAV and four HEV genotypes (Krain et al. 2014; Lemon et al. 2017). Despite this genetic diversity, only single HAV and HEV serotypes have been described. Antibodies capable of cross-genotype neutralization are elicited by natural infection and vaccination (Krain et al. 2014; Lemon et al. 2017). Neutralizing antibodies directed against the HAV and HEV capsid proteins provide protection from infection (Krain et al. 2014; Lemon et al. 2017), and at least in the case of HAV prevent or blunt symptoms of acute hepatitis when administered within the first 2 weeks of the 3- to 4week incubation phase of infection (Lemon et al. 2017). Precisely how antibodies neutralize these viruses and whether they contribute to resolution of infection is not known. Until recently, it was assumed that HAV and HEV existed in blood, liver, and feces as naked particles susceptible to antibody neutralization. The observation that most if not all HAV and HEV particles circulating in blood are cloaked in host cell membranes, a state defined as quasi-envelopment (Feng et al. 2013; Yin et al. 2016), has rekindled interest in virus spread in the liver and susceptibility to antibody neutralization (Feng et al. 2013; Yin et al. 2016). Below, the characteristics of antibody responses against these viruses are reviewed and their potential to limit spread in liver during acute HAV and HEV infection is discussed.

\section{The Hepatitis A Virus}

Evidence that antibodies protect against acute hepatitis A first emerged from a remarkable series of experiments conducted 30 years before isolation of the virus. The rationale for the first successful test of passive immunization with immune gammaglobulin was described by Stokes and Neefe (1945):

Because the virus agent responsible for epidemic or infectious hepatitis is present in blood during the preicteric and early icteric phases of disease, it seemed reasonable to postulate that such neutralizing antibodies in gamma globulin might be effective in aborting or in attenuating this disease if administered during the incubation period or preicteric stage.

To test this hypothesis, gammaglobulin from convalescent donors was transferred to children at high risk of infectious hepatitis because of a severe epidemic during summer camp. A dramatic decline in overt hepatitis was reported in the treatment group receiving gammaglobulin versus an untreated control group, suggesting that this approach prevented infection and/or the development of acute hepatitis (Stokes and Neefe 1945). Successful use of immune gammaglobulin to prevent infectious hepatitis was also reported in 1945 by Havens and Paul during an epidemic at a New Haven, CT, orphanage (Havens and Paul 1945), and by Gillis and Stokes in a study of military personnel deployed in the Mediterranean theater of operations during World War II (Gellis et al. 1945). The modern era for analysis of antibody-mediated protection against acute type A hepatitis did not arrive until 1973, however, when Feinstone, Purcell, and Kapikian used immune electron microscopy (IEM) to visualize viral antigen in stool samples from infected humans (Feinstone et al. 1973; see Feinstone 2018 for details). IEM was also used to provide the first evidence of seroconversion to the presumptive viral capsid antigen using paired serum samples from subjects experimentally infected with HAV (Feinstone et al. 1973). 
Kinetic and Durability of the Antibody Response in Acute and Relapsing HAV Infection

Immune electron microscopy was a cumbersome approach for characterization of antibodies that bind the HAV capsid. Rapid development of more facile assays, including radioimmunoassay (RIA) and enzyme-linked immunosorbent assays (ELISA), revealed that the acute phase antibody response against the HAV capsid is comprised of IgM, IgA, and IgG isotypes (Stapleton 1995). Anti-HAV IgM seroconversion occurs approximately coincident with the onset of jaundice and other physical signs of acute hepatitis (Fig. 1A) (Lemon et al. 2017). IgM antibody titers then typically decline to undetectable levels within 4-6 months. Because of the early and transient nature of the response, anti-HAV IgM has been described as an acutephase antibody that is diagnostic of HAV infection. Anti-HAV IgA appears in serum at about the same time as the IgM response (Sikuler et al. 1983; Stapleton et al. 1991), and HAV:anti-HAV IgA complexes are present in the stool of some individuals during the later phases of acute infection (Locarnini et al. 1980). Anti-HAV IgG also appears in serum during the acute symptomatic phase of infection, but titers are initially lower and increase more slowly than those of the IgM isotype (Fig. 1A). The IgG response to HAV is remarkably durable, persisting for life in most individuals after convalescence from acute hepatitis A (Lemon and Binn 1983). The IgG antibody response targets major capsid proteins VP1, VP2, and VP3 (Wang et al. 1996) as well as nonstructural HAV proteins (Jia et al. 1992). Although probably not important for control of infection, antibodies against individual nonstructural proteins like the $3 \mathrm{C}^{\text {pro }}$ proteinase can be used to distinguish humoral responses that are a consequence of infection versus vaccination with inactivated HAV capsid particles (Stewart et al. 1997). The kinetic of the serum anti-HAV antibody response matches the timing of hepatic antibody and B-cell gene up-regulation observed more recently in experimentally infected chimpanzees. Genes encoding the three antibody heavy chain isotypes as well as numer- ous other genes associated with B-cell activation and homing to liver are strongly up-regulated at about 3-4 weeks after challenge with HAV (Lanford et al. 2011). Factors that contribute to the robust and durable antibody response against HAV are not defined, but it is noteworthy that quasi-enveloped HAV efficiently activates plasmacytoid dendritic cells ( $\mathrm{pDCs}$ ), resulting in $\mathrm{pDC}$ migration to the liver during acute HAV infection and production of cytokines, including interferon (IFN)- $\alpha$ (Feng et al. 2015), which is known to promote B-cell differentiation into plasma cells (Jego et al. 2003). These observations are consistent with expansion of plasma blasts that secret IgM against the HAV capsid (Hong et al. 2013). Plasma cells also infiltrate liver, a finding that typifies hepatitis $\mathrm{A}$ and is rare in other types of viral hepatitis.

Approximately 5\%-10\% of acute HAV cases relapse, usually in older patients who may not sustain effective antiviral immune responses (Schiff 1992). Relapse is characterized by a resurgence in HAV replication and symptoms of hepatitis a few weeks after control of the primary infection (Fig. 1B) (Sjogren et al. 1987). The course of relapsing hepatitis A is sometimes prolonged but the virus is ultimately cleared (Fig. 1B). Whether the anti-HAV antibody response develops with a typical kinetic in individuals with relapsing hepatitis A is largely unknown. Serum anti-HAV IgM antibodies persist in individuals with relapsing infections for reasons that are not yet understood (Fig. 1B) (Jacobson et al. 1985; Cobden and James 1986; Glikson et al. 1992; Schiff 1992). Relatively little is known about the timing and neutralizing function of anti-HAV IgG antibodies, or their capacity to prevent resurgent HAV replication (Fig. 1B).

\section{Antibody Neutralization of HAV}

Adaptation of HAV for replication in cultured primary and established cell lines facilitated studies of antibody-mediated neutralization of infectivity (Frosner et al. 1979; Daemer et al. 1981; Gauss-Muller et al. 1981; Kojima et al. 1981). Because HAV replication in these culture models was persistent and noncytopathic (Frosner et al. 1979; Daemer et al. 1981; Gauss-Muller 


\author{
C.M. Walker
}

A

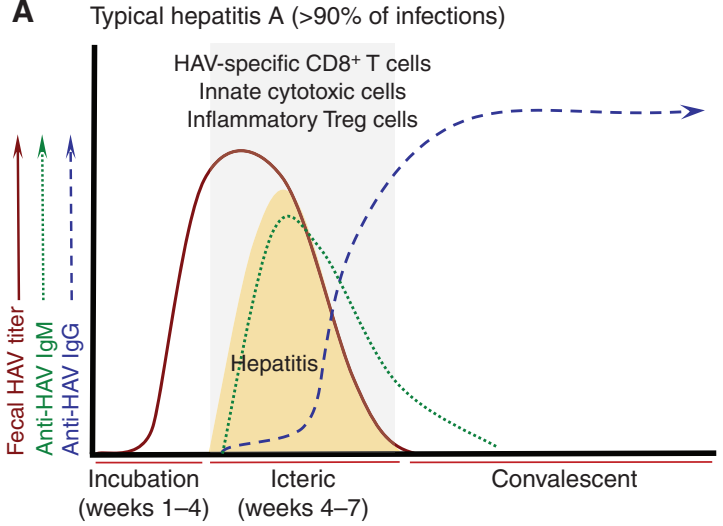

B Relapsing hepatitis A ( $>10 \%$ of infections)

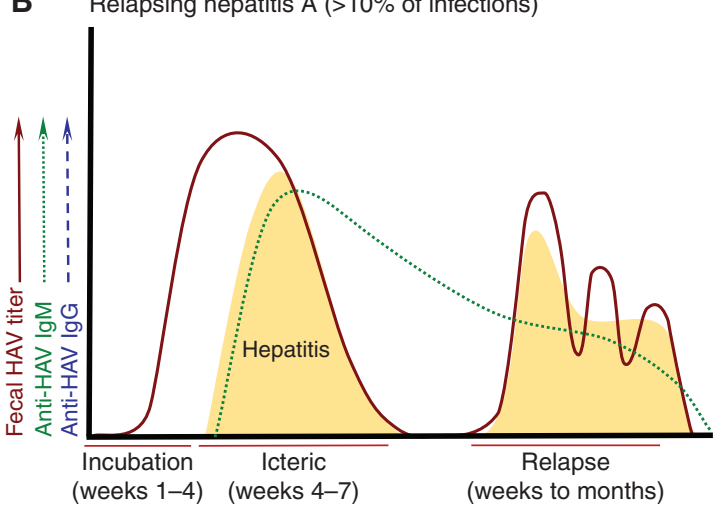

Typical HAV infection: unresolved questions in adaptive immunity

How does passive or active immunization in the first 10-14 days of infection prevent hepatitis?

What is the kinetic and functional profile of HAV-specific CD4 ${ }^{+}$and $C D 8^{+} \mathrm{T}$ cells?

Is there a temporal kinetic relationship between functional T-cell responses, viral control, and the onset of hepatitis?

Are $\mathrm{CD}^{+} \mathrm{T}$ cells required for control of infection or as a cause of acute hepatitis?

What is the major immune mechanism of liver injury, and why is severity so variable?

Do anti-HAV IgG antibodies assist in clearance of quasi-enveloped HAV viruses?

\author{
Relapsing HAV infection: unresolved \\ questions in adaptive immunity \\ Are HAV-specific CD4 ${ }^{+}$and $\mathrm{CD}^{+}$T-cell responses \\ similar to those in typical infections? \\ Is relapse caused by a failure to sustain $\mathrm{CD}^{+}$or \\ $\mathrm{CD}^{+} \mathrm{T}$ cells in the convalescent period? \\ Why does the IgM antibody response persist in \\ relapsing HAV infection?
}

What is the kinetic of the anti-HAV IgG response, and is it generated or sustained in relapsing infections?

Figure 1. Adaptive immunity in hepatitis A virus (HAV) infection. (A) Typical hepatitis A. The majority $(>90 \%)$ of acute HAV infections are characterized by an incubation phase of 3-4 weeks followed by an icteric phase of 2-4 weeks (see Shin and Jeong 2018). Hepatitis, which is thought to be immune mediated, is highly variable in severity. It ranges from clinically inapparent in young children to more severe in older children and adults. Serum anti-HAV IgM antibodies appear within a few days of the onset of hepatitis and generally become undetectable within 4 months. Anti-HAV IgG antibody titers increase in the late symptomatic phase and remain detectable for life. HAV-specific $\mathrm{CD}^{+} \mathrm{T}$ cells have been detected in blood and liver of patients during the icteric phase (Vallbracht et al. 1986, 1989; Fleischer and Vallbracht 1991; Schulte et al. 2011), and probably decline in frequency with resolution of the infection (Schulte et al. 2011). Recent studies have also described expansion of innate cytotoxic cells and T regulatory (Treg) cells that have converted to an inflammatory phenotype in individuals with symptomatic infections (Choi et al. 2018b; Kim et al. 2018). CD $4^{+}$and CD $8^{+}$T-cell frequency and function have been described in too few studies to superimpose kinetic curves on the profile of resolving HAV infections. Key unanswered questions about adaptive immune responses in acute hepatitis A are shown to the right. (B) Relapsing hepatitis A. Approximately 5\%-10\% of acute HAV infections relapse about 1-4 months after apparent resolution of symptoms and virus replication. Very little is known about adaptive immune responses in this uncommon but fascinating atypical form of the infection. Anti-HAV IgM responses persist through the relapse phase, and therefore are sustained for a longer period of time when compared with typical infections that do not relapse. Little is known about the anti-HAV IgM response or the nature of T-cell immunity during the primary or relapsing phases of infection. It is likely that failure to develop or sustain a virus-specific humoral or cellular immune response facilitates relapse of infection. It is important to emphasize that even relapsing infections eventually resolve, and persistence of HAV has not been described under conditions that lead to chronic hepatitis E virus (HEV) infection. 
et al. 1981; Kojima et al. 1981), an alternative to the classical plaque reduction assay was needed to measure neutralization. The immediate solution was a radioimmune focus assay (RIFA) that provided autoradiographic images of HAV-infected cell foci that developed beneath an agarose overlay (Lemon and Binn 1983). Inhibition of focus formation by serum antibodies from acutely infected humans and nonhuman primates provided the first evidence of a neutralizing response against HAV (Lemon and Binn 1983). Using this approach, it was demonstrated that serum-neutralizing antibodies developed about 1 week before a transaminase elevation in experimentally infected owl monkeys (Lemon and Binn 1983). The appearance of neutralizing antibodies also correlated with reduced fecal HAV shedding in these animals. Analysis of serum samples from military personnel infected during an outbreak of HAV revealed a similar neutralizing response to the virus (Lemon and Binn 1983). Rate zonal centrifugation of serum samples documented HAV neutralizing activity in the 7S (IgG) and 19S (IgM) fractions (Lemon and Binn 1983). Neutralizing activity in the 19S fraction was early and transient, as expected from the kinetic of the anti-HAV IgM response (Lemon and Binn 1983). Neutralizing activity was not consistently detected in the 7S fraction until later in infection when anti-HAV IgG titers increased. In general, however, serum antibodies collected during the late or convalescent phase of infection provided more robust HAV neutralization than serum samples collected in the early acute phase of infection (Lemon and Binn 1983; Zahn et al. 1984). This may indicate that the relative efficiency of neutralization is greater for the late IgG versus early IgM antibody response.

Development of anti-capsid monoclonal antibodies facilitated mapping of neutralizing epitopes. An early study employed the RIFA assay and physicochemical approaches to partially localize a neutralizing domain to the capsid protein VP1 (Hughes et al. 1984). HAV neutralization escape variants selected with monoclonal antibodies in cell culture models accelerated epitope identification (Ping et al. 1988; Ping and Lemon 1992). The studies revealed that a dominant conformational (discontinuous) epitope formed from VP1 and VP3 is targeted by neutralizing antibodies (Stapleton and Lemon 1987; Ping et al. 1988; Ping and Lemon 1992). Recent visualization of the HAV capsid structure by Xray crystallography provided structural details of this epitope (Wang et al. 2015). Another conformational neutralizing epitope was recently localized to amino acid residues of VP2 and VP3 targeted by antibodies that destabilize the capsid, perhaps by acting as a receptor mimic (Wang et al. 2017). Conservation of these structures across HAV genotypes that infect humans is consistent with neutralization studies that documented a single serotype.

\section{Antibody-Mediated Protection against HAV Infection}

Multiple lines of evidence indicate that antibodies generated by natural infection or vaccination with inactivated HAV particles are sufficient to protect against infection. Lifelong protection from HAV reinfection is strongly associated with neutralizing anti-HAV IgG antibodies elicited by natural infection (Lemon and Binn 1983). The formalin-inactivated HAV vaccine also provides protective immunity as effective and durable as that conferred by natural infection. Priming and boosting with the formalin-inactivated vaccine generates anti-HAV antibody titers similar to those measured after natural infection, and greatly exceed the minimum 10 international units (IU)/mL that is considered protective (Lemon et al. 1997). High titer anti-HAV antibodies present in the serum of most infected and vaccinated individuals may well provide sterilizing immunity against infection. In support of this view, monkeys (D'Hondt et al. 1995) and chimpanzees (Purcell et al. 1992) challenged with HAV after immunization with the formalin-inactivated vaccine had no virological, serological, or biochemical evidence of infection. Vaccine-induced antibodies may provide protection even when titers are at or below the limit of detection by binding and neutralization assays. This was shown in a study of chimpanzees challenged with HAV after transfer of immune globulin from vaccinated and convalescent humans (Purcell et al. 1992). At the time of HAV 
challenge, serum titers of passively transferred antibodies were much lower than those typically generated by infection or vaccination. All chimpanzees were infected after challenge, as assessed by fecal HAV shedding and a sharp increase in serum anti-HAV IgM antibodies. Unlike untreated control animals, however, none of the recipients of passively transferred antibodies had histological or biochemical evidence of acute hepatitis A (Purcell et al. 1992). Together, these studies indicate that antibody titers generated by infection or vaccination are usually sufficient to provide apparent sterilizing immunity. Even when titers are too low to protect against breakthrough infection, anti-HAV antibodies may still prevent the onset of acute hepatitis.

\section{Postexposure Antibody Therapy and Protection from Acute Hepatitis}

As noted above, prevention of symptomatic infectious hepatitis by passive immunization with immune gammaglobulin from convalescent donors was documented decades before discovery of HAV. Gammaglobulin was most effective if administered early in the incubation phase of infectious hepatitis, ideally 1 week or more prior to the onset of symptoms. Postexposure treatment of infected subjects also appeared to attenuate liver disease, as jaundice lasted for 7 days or less in the few gammaglobulin-treated individuals who developed symptoms, versus 14 days or more in the untreated group (Stokes and Neefe 1945). Finally, passive immunization appeared to provide durable protection from infectious hepatitis for approximately 6 months (Stokes et al. 1951).

These parameters defining the timing, effectiveness, and duration of gammaglobulin protection remained largely unchanged with more contemporary studies of postexposure protection by anti-HAV antibodies (Conrad and Lemon 1987; Green and Dotan 1988). Antibodies that bind the HAV capsid and neutralize infectivity are present in serum after passive immunization with commercial immune globulin preparations (Lemon et al. 1997). In general, anti-capsid antibody titers measured approximately 1 week after passive immunization are similar to those generated by active immunization with the formalin-inactivated vaccine, but decline over time with a kinetic that is predictable based on the known half-life of serum immunoglobulins (Lemon et al. 1997). The neutralization titer of anti-HAV antibodies may be higher immediately after passive immunization than those generated by single dose of the formalin-inactivated vaccine (Lemon et al. 1997). This could reflect enhanced maturation and/or affinity of antibodies generated during natural HAV infection of gammaglobulin donors. Precisely how postexposure administration of immune globulin prevents acute hepatitis in individuals who are already infected is not known. It is likely that anti-HAV antibodies restrict spread of the virus within the liver, perhaps by neutralizing infectivity of quasi-enveloped particles after endosomal uptake. This antiviral effect is strong, as the majority of individuals treated within the first 2 weeks of HAV exposure do not generate a de novo anti-HAV antibody response despite the likelihood that some virus replication and capsid production occurred in the liver (Sonder et al. 2004; Whelan et al. 2013). In some studies, a small but significant percentage of immune globulin recipients seroconverted but were nonetheless protected from hepatitis (Sonder et al. 2004). It is likely that sufficient HAV antigen was produced to trigger an adaptive immune response, even if virus replication and attendant hepatitis were profoundly suppressed by passively transferred anti-HAV antibodies. Antibodies generated as a consequence of subclinical infection might be expected to provide protection that outlasts those expected from passive immunization alone. This concept, termed "passive-active immunization," was proposed in the earliest studies of postexposure gammaglobulin therapy to explain durable, perhaps lifelong protection, observed in some study subjects (Stokes et al. 1951).

With successful development of the formalin-inactivated vaccine to prevent HAV infection, studies were undertaken to determine whether active immunization in the postexposure period could also prevent clinically apparent hepatitis A. Two studies in nonhuman primates provided early support for this concept. In 
the first, two chimpanzees received the formalin-inactivated vaccine 1 or 3 days after challenge with HAV (Robertson et al. 1994). The animal that received vaccine 3 days after challenge was not infected. Fecal shedding of HAV was also not detected in the animal vaccinated 1 day after challenge, but a sharp boost in anti-HAV antibodies provided serologic evidence of infection (Robertson et al. 1994). Acute hepatitis in this chimpanzee was attenuated compared to two unvaccinated control animals that followed a typical course of acute hepatitis A after challenge. Similar results were obtained in marmosets that were vaccinated after HAV challenge (D'Hondt et al. 1995). Vaccination of marmosets at 48 hours after challenge prevented fecal shedding of virus and transaminase elevations even though the animals were clearly infected as determined by visualization of viral capsid antigen in liver (D’Hondt et al. 1995). Postexposure vaccination therefore limited HAV spread and acute inflammation within the liver, as well as HAV shedding that perpetuates sporadic and epidemic transmission of the virus. Studies of postexposure immunization undertaken in humans confirmed that the formalin-inactivated vaccine can modify the course of acute hepatitis A. One large field study compared passive versus active immunization for protection against hepatitis $\mathrm{A}$ in contacts of individuals with confirmed HAV infection (Victor et al. 2007). Gammaglobulin and the formalin-inactivated vaccine were both administered within an average of 10 days of exposure to the virus. Rates of hepatitis among contacts who received vaccine or immune globulin did not exceed 5\%, indicating that both approaches are highly effective in prevention of disease (Victor et al. 2007). A very modest protective advantage was observed for immune globulin, but active vaccination has other significant advantages including perceived safety and lifelong protection from HAV infection in regions where the virus is endemic.

\section{HAV Evasion of Neutralizing Antibodies}

Mutational escape of capsid epitopes does not contribute to immune evasion from neutralizing antibodies elicited by infection or vaccination.
As noted above, the dominant capsid neutralizing epitope is conserved in all HAV strains circulating in humans and there appears to be robust negative selection pressure against emergence of genetically stable immune escape variants (Lemon et al. 1990). One study did describe six HAV variants with amino acid substitutions at VP1 residues in close proximity to those comprising the major neutralization epitope (Perez-Sautu et al. 2011). Introduction of the conservative and semiconservative amino acid substitutions into cell-culture-adapted viruses resulted in evasion of antibody neutralization and successful competition against the more fit parental HAV strain (Perez-Sautu et al. 2011). Nonetheless, the genetic stability of these viruses in nature is questionable given their reduced replicative fitness and the apparently rare emergence of escape variants in human populations. This concept is supported by studies of owl monkeys experimentally infected with an antigenic variant of HAV that was highly adapted for replication in cell culture and resistant to neutralization by monoclonal antibodies (Lemon et al. 1990). Resistance was conferred by a single amino acid substitution in the VP3 protein of the HAV capsid. The mutation was not stable in the infected animals as viruses with wild-type capsid sequences dominated in feces and liver by about week 3 of infection when hepatitis developed (Lemon et al. 1990).

The effectiveness of the neutralizing antibody response in preventing spread of HAV in the liver may be limited by cloaking of the HAV capsid in host cell membranes. Efficient transmission of infection between humans is mediated by naked HAV particles that lack an envelope component when shed in stool. Serum IgM and IgG antibodies readily neutralize infectivity of this form of the virus. However, most HAV particles acquire a quasi-envelope as they are released from hepatocytes into circulation (Feng et al. 2013) and bile (HiraiYuki et al. 2016b). This envelope provides protection from IgM or IgG neutralizing antibodies that block virus attachment or entry at the cell membrane (Feng et al. 2013; Hirai-Yuki et al. 2016b). Quasi-enveloped HAV is neutralized by IgG after entry into the cell, quite possibly 
in the endosome where particle uncoating occurs (Feng et al. 2013; Hirai-Yuki et al. 2016b). Anti-HAV IgM antibodies do not mediate postentry neutralization (Feng et al. 2013; HiraiYuki et al. 2016b). This may reflect restricted access or structurally instability of large pentameric IgM molecules in the endolysosomal compartment. Envelope cloaking may therefore provide an important mechanism for HAV to evade the IgM response that dominants the early phase of acute infection.

\section{Anti-HAV Antibodies and HAV Trafficking}

As noted above, HAV is complexed with antiHAV IgA antibodies in the stool of some patients after seroconversion. Antibody-mediated neutralizing activity is nonetheless uncommon in fecal samples (Stapleton et al. 1991), and the need for a secretory IgA response to control local enteric replication is questionable given limited evidence for HAV infection of the gastrointestinal (GI) tract. Anti-HAV IgA antibodies could serve an entirely different function by acting as a chaperone for HAV trafficking between the GI tract and liver. There is evidence that the efficiency of virus transit across the polarized epithelium of the gut is enhanced by antivectorial transcytosis of HAV:anti-HAV IgA complexes (Dotzauer et al. 2005), a process that could deliver the virus to the bloodstream and ultimately the liver where it replicates. The observation that $\mathrm{HAV}$ :anti-HAV IgA complexes also bind the asialoglycoprotein receptor on hepatocytes, thereby enhancing virus entry and replication (Dotzauer et al. 2000), provides additional compelling evidence that IgA may regulate enterohepatic trafficking of HAV. More recently, it was demonstrated that IgA also enhances transcytosis of HAV from the basal to apical membrane of hepatocytes and export into bile in a rodent model of antibody facilitated virus trafficking (Counihan and Anderson 2016). Together, these observations suggest that the normal protective function of IgA may be co-opted by HAV to increase the efficiency of liver infection and transmission of this enteric hepatitis virus. However, the significance of these mechanisms to the pathogenesis of acute HAV infec- tion is not entirely clear given high levels of fecal virus shedding that occur before seroconversion. One recent study in a murine model suggested that IgA-mediated enhancement of HAV translocation from the gut might facilitate reinfection of the liver, especially if the competing IgG antibody response is weak or delayed (Dotzauer et al. 2012). This mechanism may therefore be relevant to prolonged or relapsing HAV infections where IgG production is delayed, although this remains to be established.

\section{The Hepatitis E Virus}

Seroconversion against the agent of enteric nonA, non-B hepatitis was demonstrated in a human subject who developed acute hepatitis after ingestion of pooled fecal material from patients with enterically transmitted non-A, nonB hepatitis (Balayan et al. 1983). Using IEM, serum antibodies that developed during the preclinical and early postclinical phases of infection were used to visualize spherical virus particles of about 27-30 nm in fecal samples (Balayan et al. 1983). Follow-up studies demonstrated that serum antibodies collected from well-documented cases of enterically transmitted non-A, non-B hepatitis from Asia, Africa, and North America also reacted with these particles, providing early evidence that the causative viruses from different regions of the world were serologically related (Bradley et al. 1988). Moreover, seroconversion was documented in macaques experimentally challenged with the infectious etiological agent (Bradley et al. 1988). Molecular cloning of the HEV genome from bile of one experimentally infected macaque facilitated expression of recombinant open reading frame (ORF) 2 capsid protein that could be used to characterize the antibody response in infected humans (Reyes et al. 1990).

\section{Kinetic and Durability of the Antibody Response in Acute and Chronic HEV Infection}

The relationship between seroconversion, transaminase elevation, and HEV viremia or fecal shedding appears to be very similar in acute $\mathrm{HEV}$ and $\mathrm{HAV}$ infections. The profile for HEV 
emerged from multiple studies of populations infected during sporadic and epidemic spread of HEV (Bryan et al. 1994; Clayson et al. 1995; Chandra et al. 2010; Huang et al. 2010), and individuals who were infected experimentally (Chauhan et al. 1993) or accidentally (Sarkar et al. 2015) with the virus. Anti-HEV IgM is first detected in serum at about the time serum transaminases increase (Fig. 2A). The IgM antibody response declines sharply just after convalescence and is diagnostic of acute primary infection. An anti-HEV IgA response is also commonly detected during the early phase of infection (Chau et al. 1993), approximately coincident with onset of the IgM response. It has therefore been proposed that detection of $\operatorname{IgA}$ can also be used to identify cases of acute primary HEV infection (Takahashi et al. 2010). Serum anti-HEV IgG antibodies against the ORF2 capsid are detected at the later stages of acute hepatitis E, and increase in titer (Bryan et al. 1994; Huang et al. 2010) and avidity (Zhang et al. 2002) with convalescence (Fig. 2A). Follow-up of patients for 1-2 years after recovery from acute hepatitis $\mathrm{E}$ indicated that IgG antibody titers declined with time but nonetheless persisted in all individuals (Bryan et al. 1994; Huang et al. 2010). Evidence that serum antibodies persist for a very long time was obtained in a study of subjects infected during a 1978 epidemic in Kashmir. Anti-HEV seropositivity was not statistically different when samples collected during the acute phase of infection and 14 years after convalescence were compared (Khuroo et al. 1993). Recurrent exposure to HEV did not appear necessary to maintain antibody positivity in this population (Khuroo et al. 1993).

Despite this evidence for durable and perhaps lifelong humoral immunity, there is also a body of literature supporting the controversial concept of seroreversion after resolution of HEV infection (Krain et al. 2014). Early studies demonstrating seroreversion are difficult to interpret as they were undertaken with assays for anti$\mathrm{HEV}$ antibodies that varied widely in sensitivity and specificity. International anti-HEV antibody reference standards were not available until recently, further complicating comparison of assays and study findings. One recent retrospec- tive study with well-characterized detection assays documented loss of anti-HEV IgG in approximately half of subjects multiply transfused for treatment of genetic disorders (Servant-Delmas et al. 2016). Seroreversion was observed approximately 7 years after first detection of anti-HEV IgG (Servant-Delmas et al. 2016). Further study in nontransfused populations is required to determine whether seroreversion is a common event. Finally, the broad outline of humoral responses presented here is based mostly on studies of clinically apparent HEV gt1 infections during periods of endemic or epidemic virus transmission. Other recent studies have established that the timing and isotype profile of the humoral response is similar in acute resolving $\mathrm{HEV}$ gt3 or gt4 infections that are zoonotic or transfusion-related and more often clinically silent (Bendall et al. 2008; Takahashi et al. 2010; Vollmer et al. 2016).

Antibody responses against the ORF2 capsid have also been characterized in patients with chronic HEV gt3 infections. In overview, the kinetic of the anti-HEV IgM and IgG responses varies greatly among patients with chronic hepatitis E, perhaps reflecting differences in underlying disease and immune-suppressive regiments. Because of this individual variability, the kinetic of anti-HEV antibody responses and HEV replication or outcome of the persistent infection are not readily compared (Fig. 2B). Persistence of HEV in the absence of seroconversion has been described in some patients, while others do develop detectable IgM and/or IgG responses (Dalton et al. 2009; LegrandAbravanel et al. 2010; Pas et al. 2012; Suneetha et al. 2012; Kamar et al. 2013; Moal et al. 2013). Two representative studies demonstrated that anti-HAV IgM seroconversion can be delayed for months in persistently infected patients treated with immune-suppressive drug regimens to prevent allograft rejection (LegrandAbravanel et al. 2010; Choi et al. 2018a). Moreover, the IgM response can persist throughout chronic infection, far longer than responses in individuals with typical acute resolving infections (Fig. 2B) (Legrand-Abravanel et al. 2010; Choi et al. 2018a). A similar delay in generation of humoral immunity and cocirculation of per- 
C.M. Walker
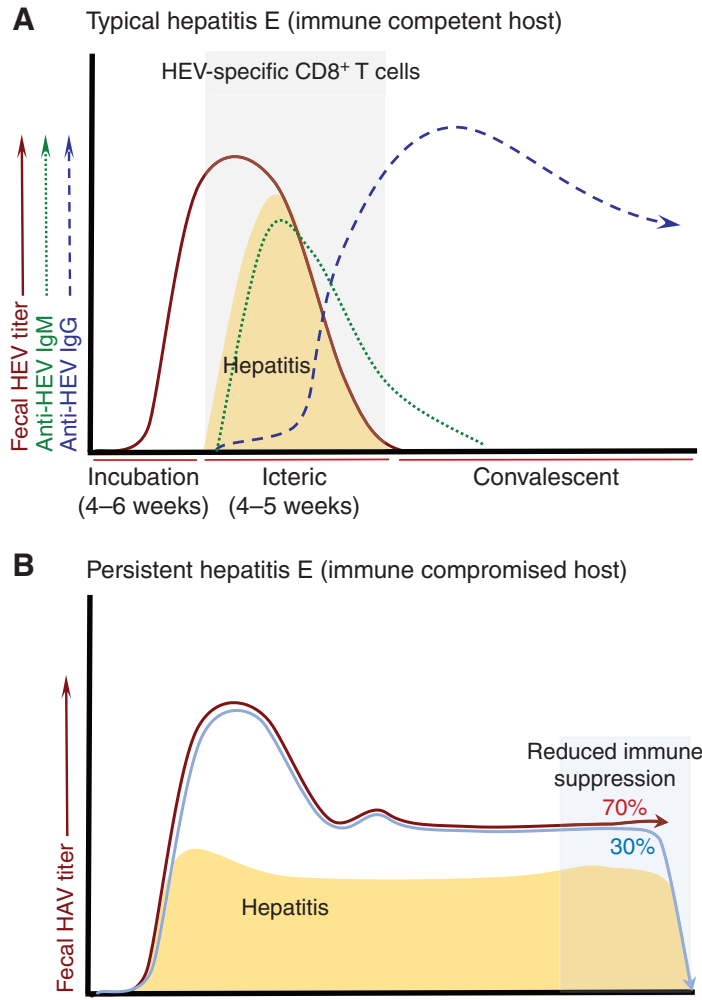

Typical HEV infection: unresolved questions in adaptive immunity

What adaptive immune responses are required to prevent $\mathrm{HEV}$ persistence $\left(\mathrm{CD} 4^{+}\right.$and/or $\mathrm{CD}^{+}$ T cells, neutralizing anti-HEV antibodies?)

Do anti-HEV neutralizing antibodies persist for life as in HAV infection, and under what conditions do they fail to provide protection from reinfection?

What is the major immune mechanism of liver injury; why is severity so variable especially in women at the late stages of pregnancy?

Do anti-HEV IgG antibodies assist in clearance of quasi-enveloped HAV viruses?

Can passive or active immunization prevent hepatitis as described in HAV infection and, if not, why do antibodies fail to provide postexposure prophylaxis?

Persistent HEV infection: unresolved questions in adaptive immunity Is recovery of $\mathrm{CD}^{+}$and/or $\mathrm{CD}^{+} \mathrm{T}$-cell immunity required for resolution of persistent infection after immune suppression is reduced?

How does HEV continue to persist in about $70 \%$ of individuals even after a reduction in immune suppression?

Does HEV persist in the presence of neutralizing anti-HEV IgG antibodies?

Figure 2. Adaptive immunity in hepatitis E virus (HEV) infection. (A) Typical hepatitis E. The course of acute $\mathrm{HEV}$ infection is very similar to that described for hepatitis A virus (HAV) infection. An incubation phase of 3-4 weeks can be followed by a period of overt hepatitis that persists for about an additional 2-4 weeks (see Aggarwal and Goel 2018). However, many HEV infections in adults are clinically inapparent, especially those caused by genotype 3 viruses. The anti-HEV antibody profile is also similar to HAV infection, with an early IgM response that transitions to an IgG isotype during the later stages of acute infection. The IgG response is typically durable after convalescence, but there is evidence that titers fall below protective thresholds in some patients who are susceptible to reinfection. How commonly seroreversion occurs and whether the severity and duration of second infections is reduced is not yet known. HEV-specific $\mathrm{CD}^{+} \mathrm{T}$-cell activity has been detected in the blood of infected patients who had symptoms of acute infection (Suneetha et al. 2012; Brown et al. 2016). Whether expansion of functional cytotoxic $\mathrm{CD}^{+} \mathrm{T}$ cells is temporally associated with control of virus replication or the timing and severity of liver disease remains to be determined. To date there has been no analysis of other cytotoxic cell populations during acute infection, including those of the innate lineage, as has been described for HAV. Importantly, it is not yet known whether antibodies contribute to resolution of infection with this quasienveloped virus and is somewhat difficult to predict because there is as yet no positive demonstration that passive transfer of anti-HEV antibodies during the incubation phase of infection will prevent or temper hepatitis. The minimum humoral or cellular responses required to prevent HEV persistence have not yet been identified. Key unanswered questions about adaptive immune responses in acute hepatitis $\mathrm{E}$ are summarized to the right of the panel. (B) Persistent hepatitis E. HEV infection persistence has been described in individuals with compromised immunity caused by hematological malignancies, organ allograft, and HIV coinfection. HEV-specific T-cell responses are clearly reduced or undetectable in these patients (Suneetha et al. 2012; Brown et al. 2016), but appear to strengthen at least transiently with resolution of infection (Suneetha et al. 2012). The timing and magnitude of anti-HEV IgM and IgG responses in chronically infected patients is highly variable and difficult to generalize; persistence of HEV in the absence of seroconversion has been described in some patients, while others do develop detectable IgM and/or IgG responses (Pas et al. 2012; Kamar et al. 2013; Moal et al. 2013). Studies in solid organ transplant recipients demonstrated that IgM seroconversion can take months to develop, and the IgM response appears to persist throughout chronic infection (Legrand-Abravanel et al. 2010; Choi et al. 2018a). 
sistent virus with anti-HEV IgG was also described in macaques experimentally infected with an HEV gt3 isolate during treatment with immune-suppressive drugs (Gardinali et al. 2017). It could be concluded from these observations that antibodies are of limited importance in virus control during chronic infection, but comprehensive analysis of anti-HEV IgG titers, avidity, and neutralizing capacity has not yet been reported.

\section{Antibody Neutralization of HEV}

Adaptation of HEV for replication in cultured cells provides an experimental model to assess antibody-mediated neutralization of infectivity (Emerson et al. 2006; Tanaka et al. 2007, 2009; Shukla et al. 2011). Even with this advance, the paucity of literature describing neutralizing antibody responses during acute and chronic HEV infections and after preventive vaccination is striking. This may reflect in part the technical difficulty in measuring replication of this noncytopathic virus in cell culture models. Readouts include PCR-based quantification of HEV RNA and visualization of infected cell foci by immune fluorescence assay that are semiquantitative or cumbersome and time consuming. In the very limited number of settings where these assays were used, direct evidence for HEV neutralization by acute and convalescent phase serum antibodies was obtained. As an example, serum collected from one individual with an acute HEV gt3 infection had high titers of ORF2binding IgM and IgG antibodies that efficiently neutralized infectivity of virus derived from stool but not serum (Takahashi et al. 2010). Anti-capsid IgG but not IgM antibodies were present in a second serum sample collected almost 6 years after convalescence. The capsidbinding titer was 10 -fold lower titer than that measured during acute infection, but the antibodies still neutralized fecal-derived virus ( $\mathrm{Ta}$ kahashi et al. 2010). In another study, convalescent serum from macaques that resisted crossgenotype challenge with $\mathrm{HEV}$ (Purcell et al. 2003) was shown to efficiently neutralize HEV infectivity (Emerson et al. 2006). Surrogate neutralization assays have also been developed based on mapping of neutralizing epitopes to a domain spanning ORF2 amino acids 456-606 that form the outer shell of the capsid (Zhang et al. 2012). Panels of monoclonal antibodies directed against the ORF2 capsid were used to define two dominant neutralizing epitopes in this domain (Zhang et al. 2012).

A fragment of the ORF2 capsid protein spanning amino acids 386-606 designated p239 was the minimum unit required for selfassembly of virus-like particles (VLPs) and has been used as a highly effective vaccine that prevents $\mathrm{HEV}$ infection (Zhang et al. 2012). Binding of fluorophore-labeled VLPs formed by p239 to a hepatocyte cell line is quantifiable by high throughput flow cytometry and has been used to assess antibody-mediated neutralization (Cai et al. 2016). Importantly, assays that measured neutralization of VLP binding and neutralization of $\mathrm{HEV}$ cell culture infectivity yielded highly concordant results. The kinetic of the neutralizing antibody response was determined in experimentally infected macaques using the VLP-binding assay. In general, serum neutralizing titers obtained with this surrogate assay correlated with anti-HEV IgG antibody titers (Cai et al. 2016). For instance, the neutralizing antibody and anti-capsid IgG responses both peaked at the same time after HEV challenge, coincident with a significant decline in virus replication. Moreover, the assay was used to document a sharp increase in neutralizing antibody titers after priming and boosting of macaques with the p239 vaccine (Cai et al. 2016).

\section{Antibody-Mediated Protection against HEV Infection and Liver Disease}

Concepts of antibody-mediated protection against HEV infection and liver disease are still not as finely detailed as those described above for HAV. In overview, there is a consensus that anti-HEV antibodies elicited by vaccination or prior exposure to the virus most commonly provide cross-genotype protection against infection. HEV viremia, fecal shedding, and hepatitis are not detected in individuals with this apparent sterilizing immunity. However, there is an emerging view that secondary $\mathrm{HEV}$ infection 
characterized by limited virus replication and mild or inapparent hepatitis can develop in immune individuals with low preexisting antibody titers. Studies in immune macaques provide support for this concept. Experimental infection (Huang et al. 2008) or vaccination of animals with a recombinant ORF2 capsid protein (Tsarev et al. 1994; Purcell et al. 2003) generally elicits a high titer antibody response and complete resistance to challenge with HEV genotype-matched and mismatched viruses. It is notable, however, that a small number of macaques with low titer anti-HEV antibodies after primary infection were susceptible to reinfection (Huang et al. 2008). HEV RNA was detected in blood and stool of animals with breakthrough infections, but hepatitis was not observed (Huang et al. 2008). The possibility that antibodies protect against hepatitis when sterilizing immunity fails is also supported by passive immunization studies. Transfer of immune serum from convalescent humans to macaques 2 days before experimental HEV challenge did not prevent infection, but hepatitis was mild or absent when compared with untreated controls (Tsarev et al. 1994).

Anti-HEV antibodies generated in humans by infection or vaccination are also associated with protection from HEV. One early field study conducted during an HEV epidemic noted that all patients hospitalized for hepatitis had antiHEV IgM antibodies that define primary infection and concluded that secondary infection in immune individuals was therefore uncommon or clinically inapparent (Bryan et al. 1994). More recent analysis of sporadic and epidemic HEV outbreaks identified small numbers of subjects with serologic evidence of reinfection. In these individuals, increasing titers of high avidity anti-HEV IgG antibodies in the absence of an IgM response was considered a reliable marker of reinfection when virus replication and hepatitis were too transient or attenuated for reliable detection (Seriwatana et al. 2002; Bendall et al. 2008; Huang et al. 2010). This concept is supported by observations in an immune chimpanzee, where rechallenge with HEV 45 months after resolution of primary infection caused a sharp boost in anti-HEV IgG titer in the absence of a robust IgM response (Yu et al. 2003). Surveillance to determine the long-term efficacy of an HEV ORF2 vaccine detected a similar shift in antibody profile in some recipients with an endemic risk of HEV exposure (Zhang et al. 2015). A boost in high avidity IgG antibodies was also observed in the few vaccine recipients who acquired HEV infection (Zhang et al. 2015). Finally, reinfection was also described in the setting of solid organ transplantation. Serum anti-HEV antibodies were detected in three subjects prior to transplantation but they failed to prevent reinfection (Abravanel et al. 2016). The secondary infection persisted in the patient with the lowest anti-HEV antibody titer (Abravanel et al. 2016).

Together, these studies provide evidence that antibodies elicited by infection or vaccination do not always confer sterilizing immunity but may sharply attenuate liver disease and HEV replication when breakthrough infections do occur. Antibodies could modify the course of infection as described above for HAV but the limited studies conducted to date do not support this possibility. Postexposure treatment with immune gammaglobulin from convalescent donors failed to prevent acute hepatitis $\mathrm{E}$ in recipients (Joshi et al. 1985; Khuroo and Dar 1992), although these very early studies are interpreted with caution because anti-HEV antibodies in the donor preparations have not been characterized. It is notable, however, that active immunization of macaques with the ORF2 capsid vaccine after HEV challenge also failed to modify the course of infection when compared with unvaccinated controls (Tsarev et al. 1997). Experimental conditions were similar to those used to successfully prevent acute hepatitis A in macaques by postexposure HAV vaccination. These observations highlight the need for a better understanding of antibody-mediated neutralization of HEV in the setting of vaccination and infection, and mechanisms used by the virus to subvert this immune response.

\section{HEV Evasion of Neutralizing Antibodies}

HEV exists as a single serotype and there is no evidence that the antibody response in infected humans or animals for zoonotic infections select 
for escape variants. As described for HAV, HEV particles that circulate in blood are quasienveloped and resistant to antibody-mediated neutralization. Initial studies demonstrated that HEV particles in blood were not associated with cocirculating anti-capsid antibodies (Takahashi et al. 2010). Because these particles had a lighter buoyant density on sucrose gradients than those in stool and could not be precipitated with antibodies against the capsid unless first treated with detergent, it was concluded that they were associated with lipids (Takahashi et al. 2010). It is now clear that HEV particles acquire a quasi-envelope during their release from infected cells via the exosomal pathway (Yin et al. 2016; Chapuy-Regaud et al. 2017; Nagashima et al. 2017). Infection requires cellular uptake and uncoating of quasi-enveloped HEV particles in the endolysosome (Yin et al. 2016), and it is at this point that they become sensitive to antibody-mediated neutralization. Antibodies of the IgM isotype that arise first in primary HEV infection cannot access this cellular compartment and are therefore predicted to have limited impact on spread of quasi-enveloped HCV particles via blood. Anti-HEV IgG antibodies that arise later in acute infection can mediate intracellular neutralization of these HEV particles after uncoating as described above for HAV (Yin et al. 2016).

Very recent studies have demonstrated that HEV may have a second mechanism for evasion of antibody-mediated neutralization involving production of ORF2 capsid protein variants (Montpellier et al. 2018; Yin et al. 2018). The ORF2 protein is expressed as two variants based on translational initiation from different start codons (Yin et al. 2018), perhaps with further posttranslational processing by host cell proteases (Montpellier et al. 2018). One form of the ORF2 protein is translated from the first available start codon (Yin et al. 2018), contains a signal peptide sequence, and is directed cotranslationally to the endoplasmic reticulum where it is glycosylated and targeted for secretion via the trans-Golgi pathway (Montpellier et al. 2018; Yin et al. 2018). These proteins appear to exist as dimers and are not associated with HEV genomes. A second, shorter form of the capsid protein is translated from a downstream start codon and delivered to the virion assembly sites (Yin et al. 2018). Importantly, the glycosylated secreted long form of ORF2 is massively overproduced when compared with the shorter form destined for virus assembly (Montpellier et al. 2018; Yin et al. 2018). As expected, the long secreted form is present in serum at very high concentrations during acute and chronic infection, suggestive of a role in immune evasion. Consistent with this possibility, secreted ORF2 capsid proteins can interfere with antibody-mediated neutralization of HEV in a cell culture model (Yin et al. 2018). Whether secreted ORF2 protein can serve as sink or decoy for neutralizing antibodies, including those delivered for postexposure therapy during the incubation phase of HEV infection, remains to be determined. Additionally, a role in modulation of other innate and adaptive immune responses also cannot be excluded and merits further study. Importantly, the secreted soluble long form of the ORF2 protein does not compete with virions for receptor-mediated uptake by cells.

\section{CELLULAR IMMUNE RESPONSES}

There have been remarkably few studies of Tcell immunity against HAV and HEV. This reflects, in part, the historical emphasis on analysis of antibody responses that provide protection against infection, and in the case of HAV, blunt liver disease and transmission of the virus when deployed as postexposure prophylaxis. Progress has also been slowed by reliance on expensive nonhuman primate models of HAV and HEV infection to study mechanisms of immunity and pathogenesis in the liver. To date, there have been too few studies of adaptive cellular immunity in man or nonhuman primates to reliably superimpose the kinetic of $\mathrm{CD}^{+}$helper and $\mathrm{CD}^{+}$cytotoxic $\mathrm{T}$-cell responses on acute infection HAV and HEV profiles. As noted above, the imperative for $\mathrm{HAV}$ is to determine whether $\mathrm{T}$ cells are a cause of hepatocellular injury given the increasing burden of severe liver disease associated with a shift toward infection during adulthood in many regions of the world (see 
C.M. Walker

Jacobsen 2018). For HEV, there is a similar interest in determining the role of adaptive T-cell immunity in liver injury, especially for the HEV gt 1 and gt 2 viruses that are more frequently associated with severe and even life-threatening infections. With the description of HEV gt3 persistence, it is also important to test the commonly held view that $\mathrm{CD}^{+}{ }^{+}$and $\mathrm{CD} 8^{+} \mathrm{T}$ cells are required for successful resolution of infection. Finally, and more generally, comparative studies of $\mathrm{T}$-cell immunity against hepatitis viruses that typically do not persist (HAV and HEV) and those that do (HBV and $\mathrm{HCV}$ ) may provide insight into factors influencing infection outcome.

\section{The Hepatitis A virus}

Studies to characterize cellular responses during infectious hepatitis were undertaken decades before discovery of HAV. They ranged from a description of changes in circulating leukocyte populations in experimentally infected volunteers (Havens and Marck 1946) to development of a delayed type hypersensitivity (DTH) skin test to identify convalescent individuals with immunity to infectious hepatitis (Henle et al. 1950a; Drake et al. 1952). Remarkably, the DTH test relied on skin challenge with preparations generated by serial blind passage of infectious materials through eggs and cultured cells, and thought to contain antigens of the yet-tobe-identified hepatitis A virus (Henle et al. 1950b).

HAV-specific T-cell immunity was first documented with certainty by Vallbracht and colleagues in a series of studies conducted more than 40 years later. A cell culture model was used to demonstrate the presence of circulating HAV-specific cytotoxic T lymphocytes in seven patients with acute hepatitis A (Fig. 1A) (Vallbracht et al. 1986). Primary skin fibroblast cell lines established from these subjects supported persistent, noncytopathic replication of a human HAV isolate (Vallbracht et al. 1986). Coculture of $\mathrm{HAV}$-infected, ${ }^{51} \mathrm{Cr}$-labeled fibroblasts with peripheral blood mononuclear cells (PBMCs) from the same patient resulted in cytolysis of the targets as measured by release of the radioisotope (Vallbracht et al. 1986). Cytotoxicity peaked in blood 2-3 weeks after the onset of icterus in five patients with a typical course of acute hepatitis A. The remaining two patients had a protracted course of hepatitis that did not resolve for at least 5 months (Vallbracht et al. 1986). In these individuals, the highest cytotoxic activity against autologous HAV-infected hepatocytes was detected 8-12 weeks after the first appearance of hepatitis (Vallbracht et al. 1986). PBMCs from two uninfected control subjects did not kill virus-infected target cells, indicating that the cytotoxic activity was associated with acute HAV infection. Further characterization revealed that the circulating $\mathrm{CD}^{+} \mathrm{T}$ cells also produced IFN- $\gamma$ that enhanced HLA class I expression and directly inhibited HAV replication in cultured target cells (Maier et al. 1988). From these studies, it was concluded that $\mathrm{CD}^{+} \mathrm{T}$ cells terminate acute HAV infection by lysis of infected hepatocytes and production of IFN- $\gamma$. Infiltration of these $\mathrm{CD}^{+} \mathrm{T}$ cells into the liver was assessed in a follow-up study of two subjects with acute hepatitis A (Vallbracht et al. 1989). Mononuclear cells isolated from core liver samples taken at 12 or 38 days after the onset of hepatitis were expanded in culture with a T-cell mitogen and interleukin (IL)-2 growth factor. T-cell lines generated by this approach expressed CD8 and killed autologous HAV-infected fibroblasts. These cells fit the definition of classical cytotoxic T lymphocytes; they did not kill autologous fibroblasts that were uninfected or infected with unrelated viruses, or HLA class I mismatched fibroblasts infected with HAV. Liver function tests had not normalized in the subject biopsied at week 12 , and so it was concluded that intrahepatic $\mathrm{CD}^{+} \mathrm{T}$ cells expanded from the liver tissue contributed to hepatocellular injury in acute hepatitis A (Vallbracht et al. 1989).

Since publication of these early studies, there has been significant progress in understanding the nature of antigen recognition by antiviral $\mathrm{T}$ cells, their differentiation and function in response to infection, and in methods to characterize their phenotype, function, and frequency in blood and tissues. Two more recent studies have used these methods to better characterize 
HAV-specific T-cell immunity during acute infection. In the first study, a pool of 52 overlapping peptides spanning the HAV VP1 capsid protein was used for in vitro stimulation of PBMCs from patients with acute, postacute, and post-HAV infections (Schulte et al. 2011). IFN- $\gamma$ producing $\mathrm{CD}^{+} \mathrm{T}$-cell lines targeting 18 of these VP1 peptides were expanded in culture, demonstrating a multitude of class I epitopes in a single structural protein of the virus. VP1 epitopes presented by HLA-A11, HLA-B35, and HLA-B40 were identified using HLA class I binding algorithms and common patterns of VP1 peptide recognition by an individual who shared these alleles (Schulte et al. 2011). Another 11 candidate epitopes in HAV structural and nonstructural proteins were identified using predictive algorithms for high-affinity binding to HLA-A2 class I molecules. Of the 11 predicted epitopes, five were capable of expanding virus-specific $\mathrm{CD}^{+} \mathrm{T}$ cells from PBMCs of $\mathrm{HAV}$-infected subjects who were positive for the HLA-A2 class I allele. These epitopes were conserved in genotype $1 \mathrm{~A}, \mathrm{IB}$, IIIA, and IIIB $\mathrm{HAV}$ isolates, with the exception of one HLAA2 epitope that was not conserved in the genotype III viruses. Importantly, $\mathrm{CD}^{+} \mathrm{T}$ cells targeting a dominant epitope in nonstructural protein $3 \mathrm{D}^{\text {pol }}$ were directly visualized in the blood of six subjects using class I HLA-A2 tetramers. In one of these subjects, the tetramer analysis revealed activation of the $3 \mathrm{D}^{\text {pol }}$-specific $\mathrm{CD}^{+} \mathrm{T}$ cells during the acute phase of infection. This $\mathrm{CD} 8^{+} \mathrm{T}$-cell population was still present in blood 20 months later, well after resolution of infection, but was no longer activated and had transitioned to a memory phenotype (Schulte et al. 2011).

The second contemporary study of antiviral T-cell immunity was conducted in two HAVinfected chimpanzees (Zhou et al. 2012). Use of the animal model facilitated a kinetic analysis of HAV replication, ALT elevation, and antiviral Tcell immunity from the time of experimental challenge through resolution of infection. The infection followed a typical course in both animals. Viremia cleared and ALT normalized between 6 and 8 weeks of infection. Fecal shedding was terminated by week 14-16 postinfection when assessed by a highly sensitive PCR assay for HAV RNA. Reduced viremia and fecal shedding was kinetically associated with a circulating $\mathrm{CD}^{+} \mathrm{T}$ helper (Th) cell response that targeted multiple class II epitopes in structural and nonstructural proteins and produced a full array of Th1 cytokines, including IFN- $\gamma$, tumor necrosis factor (TNF)- $\alpha$, IL-2, and IL-21 required for generation of a cytotoxic $\mathrm{CD} 8^{+} \mathrm{T}$-cell response (Zhou et al. 2012). Indeed, $\mathrm{CD}^{+} \mathrm{T}$ cells were visualized in blood at week 4 when ALT levels spiked sharply and reached a peak frequency at week 5 when a multilog drop in viremia was observed. Importantly, however, the HAV-specific $\mathrm{CD}^{+} \mathrm{T}$ cells visualized in blood during the critical period of elevated ALT and virus control appeared to lack effector functions, including cytotoxicity and production of cytokines like IFN- $\gamma$ and TNF- $\alpha$ that have the potential to suppress HAV replication (Zhou et al. 2012). Gain of effector functions and transition toward memory by $\mathrm{CD}^{+} \mathrm{T}$ cells did not begin until virus replication was substantially controlled. These data suggested that the highly functional $\mathrm{CD} 4^{+}$ T-cell and anti-HAV antibody responses were better correlated with control of viremia than the $\mathrm{CD}^{+} \mathrm{T}$-cell response that did not develop antiviral functions until after hepatitis had subsided and HAV replication was reduced (Zhou et al. 2012). Whether this strong, multifunctional $\mathrm{CD} 4^{+} \mathrm{T}$-cell response provided direct control of HAV replication, perhaps through production of cytokines like TNF- $\alpha$ and IFN- $\gamma$ (Todt et al. 2016; Wang et al. 2016) remains to be determined.

\section{Mechanisms of Liver Injury in Acute Hepatitis A}

As noted above, wild-type HAV is not directly cytopathic for cultured cells (Frosner et al. 1979; Daemer et al. 1981; Gauss-Muller et al. 1981; Kojima et al. 1981). High levels of virus replication 3-4 weeks before the onset of acute hepatitis also suggests that the developing host response, and not virus replication, causes liver disease. The onset of the anti-HAV IgM antibody response does coincide with elevation of serum transaminases. However, serum antibodies from the acute and convalescent phase of HAV infec- 
tion did not mediate lysis of cultured HAV-infected cells even in the presence of complement (Flehmig et al. 1984), suggesting that they are not a cause of hepatitis.

Cell-mediated cytotoxicity by virus-specific $\mathrm{CD}^{+} \mathrm{T}$ cells has been considered a more likely mechanism of hepatocellular injury in acute hepatitis A, but direct evidence supporting this hypothesis is lacking. As noted above, HAV-specific $\mathrm{CD}^{+} \mathrm{T}$ cells were expanded from the blood (Schulte et al. 2011) and liver (Vallbracht et al. 1989) of patients of with acute hepatitis A, and they were directly visualized in the peripheral circulation of humans (Schulte et al. 2011) and chimpanzees (Zhou et al. 2012) with acute hepatitis A using class I tetramers (Fig. 1A). This evidence is largely circumstantial, however. There has been no direct ex vivo analysis of intrahepatic $\mathrm{CD} 8^{+} \mathrm{T}$-cell effector function and its relationship to the severity of hepatocellular injury in acute hepatitis A. The observation that circulating virus-specific $\mathrm{CD} 8^{+} \mathrm{T}$ cells in infected chimpanzees do not acquire effector functions until after transaminases normalize has led to uncertainty about their contribution to liver injury (Zhou et al. 2012).

A variety of natural killer (NK) cell types are resident in the liver. If activated during infection, they could mediate innate cytotoxic activity against HAV-infected hepatocytes or contribute to an inflammatory environment that leads to hepatocellular injury. This possibility was recognized as early as 1985 when it was demonstrated that PBMCs cultured in the presence of HAV particles produced high levels of type I IFN that in turn activated NK cells capable of killing virus-infected target cells (Kurane et al. 1985). Attention has very recently turned again to alternative mechanisms of acute liver injury in HAV-infected humans (Kim et al. 2018). These studies were undertaken during a large and prolonged HAV epidemic in South Korea that disproportionately affected adults, resulting in a substantial burden of serious acute liver disease. Analysis of peripheral blood samples from patients with acute hepatitis A revealed increased activation and proliferation of circulating $\mathrm{CD}^{+} \mathrm{T}$ cells that expressed cytotoxic molecules, the NK-cell-activating receptors NKG2D and NKp30 (Fig. 1A) (Kim et al. 2018). Remarkably, an increased frequency of these $\mathrm{CD} 8^{+} \mathrm{T}$ cells was strongly correlated with increased serum ALT levels at the time of admission. Analysis of the activated $\mathrm{CD}^{+} \mathrm{T}$ cells revealed a complex mixture of populations targeting not only HAV but also multiple other unrelated viruses, including cytomegalovirus, influenza virus, respiratory syncytial virus, and vaccinia virus. Further study demonstrated that HAV infection of cultured hepatocytes induces production of IL-15, a cytokine that can activate $\mathrm{CD}^{+} \mathrm{T}$ cells regardless of the virus they target (Kim et al. 2018). It is notable that IL-15 levels were elevated in the serum of patients in this study, suggesting that this cytokine and nonspecific $\mathrm{CD}^{+} \mathrm{T}$-cell activation is associated with severe liver disease. Finally, the authors demonstrated that activated $\mathrm{CD}^{+}{ }^{+} \mathrm{T}$ cells killed target cells through engagement of the NK cell receptors and not the T-cell receptor (Kim et al. 2018). Thus, hepatocellular injury in acute hepatitis A was associated with innate-like cytotoxicity of bystander $\mathrm{CD}^{+} \mathrm{T}$ cells after IL- 15 activation.

Further study of the same cohort of South Korean patients revealed further complexity in the pathogenesis of liver injury during acute hepatitis A (Choi et al. 2018b). Earlier studies of this cohort (Choi et al. 2015) and others (Perrella et al. 2008; Manangeeswaran et al. 2012) demonstrated that Treg cells, defined by expression of the CD4 coreceptor and the FoxP3 transcription factor, had an impaired ability to suppress effector T-cell proliferation and function during acute hepatitis A. In the follow-up study, functional alterations in circulating Treg cells were associated with more severe liver disease (Fig. 1A) (Choi et al. 2018b). As noted in earlier studies, the normal suppressive function of Tregs was reduced and they instead produced the inflammatory cytokine TNF- $\alpha$. Moreover, TNF- $\alpha$ secretion was associated with at least partial conversion to a Th17 phenotype defined by expression of the ROR $\gamma \mathrm{t}$ transcription factor, CCR6, and production of IL-17A (Choi et al. 2018b). Whether this switch of Treg to a proinflammatory posture contributes directly to liver disease was not established. Only end-stage liver was available for analysis, and the frequency of 
TNF- $\alpha$-producing Treg cells was not elevated in these samples when compared to control liver tissue (Choi et al. 2018b). However, the frequency of TNF- $\alpha$-producing Treg cells in circulation was directly correlated with transaminase elevations. It is, therefore, likely that proinflammatory conversion of Tregs during acute hepatitis $\mathrm{A}$ is a marker, if not a direct cause, of serious inflammatory liver disease in this infection. Mechanisms that underpin the loss of inhibitory function by Tregs and their acquisition of a proinflammatory phenotype have not been identified. It may be a direct consequence of other immunoregulatory events in the liver that have yet to be defined. Binding of HAV particles to $\mathrm{T}$ cells could modulate their function. For example, it has been reported that HAV impairs the function of Treg cells that express the T-cell immunoglobulin and mucin 1 (TIM-1, CD365) protein. Increased FasL-induced cell death, inhibition of T-cell receptor activation, and reduced expression of suppressive cytokines IL-10 and TGF- $\beta$ were observed when T cells were cultured in the presence of HAV particles (Manangeeswaran et al. 2012). Quasi-enveloped HAV particles could be of greatest relevance to modulation of T-cell function as this is the form that circulates in blood. Quasi-enveloped HAV particles were also recently shown to bind TIM-1 (Das et al. 2017), probably through interaction with phosphatidyl serine residues in the envelope as demonstrated for other viruses (MollerTank and Maury 2014).

Polymorphisms in the human TIM-1 immunoregulatory protein may explain in part the wide spectrum in liver disease observed in humans with acute hepatitis A (Kim et al. 2011). Two variants of the TIM-1 gene (HAVCR1) were found in patients with acute HAV infection resulting from a sporadic outbreak in Argentina. Severe hepatitis was associated with carriage of a HAVCR1 gene encoding a 6-amino-acid insertion designated 157insMTTTVP in exon 4 that had previously been linked to allergic diseases and the pathogenesis of HIV infection (Kim et al. 2011). Expression of this results in a long-form TIM-1 protein in human NKT cells that enhanced their cytolytic activity against $\mathrm{HAV}$-infected hepatocytes when compared with
NKT cells that expressed the short form of the gene (Kim et al. 2011).

In summary, the role of $\mathrm{HAV}$-specific $\mathrm{CD}^{+}$ $T$ cells in the pathogenesis of acute hepatocellular injury remains uncertain. They are present in the blood and liver of patients with acute hepatitis A. Whereas these antiviral $\mathrm{CD}^{+} \mathrm{T}$ cells could contribute to liver damage by lysis of infected hepatocytes, severity of liver disease has not yet been correlated with the magnitude and kinetic of the response. The observation that circulating $\mathrm{CD}^{+} \mathrm{T}$ cells lack effector functions until after virus replication subsides and ALT values normalize may argue against this possibility. The question of whether they are functional in the liver and are associated with cytotoxic activity at the mild or severe end of the disease spectrum requires further study. Other cytotoxic cell populations, including nonspecifically activated classical CD8 ${ }^{+} \mathrm{T}$ cells, NKT cells, and proinflammatory Treg cells, have been directly associated with the severity of acute liver disease in HAV infection. Finally, it is likely that liver injury is multifactorial because HAV infection of mice resulted in IFN-independent activation of IFN response factor 3 (IRF3) and 7 (IRF7) that mediated mitochondrial apoptosis in hepatocytes (Hirai-Yuki et al. 2016a, 2018). Importantly, antibody-mediated depletion of $\mathrm{CD}^{+}{ }^{+}$or $\mathrm{CD}^{+}{ }^{+} \mathrm{T}$ cells, or NK and NKT cells, prior to virus challenge had no ameliorating effect on the inflammatory hepatitis associated with infection in these murine studies. Whether the mechanisms reviewed here also account for fulminant hepatitis that is sometimes observed in HAV - and HEV-infected patients remains to be determined.

\section{The Hepatitis E Virus}

There is a remarkable deficit in knowledge about the contribution of adaptive T-cell immunity to the control and pathogenesis of HEV infection. The relatively recent description of persistent HEV gt 3 and gt4 infections in individuals with compromised immunity has rekindled interest in the requirement for $\mathrm{CD}_{4}^{+}$and/or $\mathrm{CD}^{+} \mathrm{T}$ cell responses in resolution of acute infection and prevention of chronic $\mathrm{HEV}$ replication 
and liver disease. As noted above, long-term persistence of HAV has yet to be described under the same conditions of immune suppression that facilitate chronic HEV infection. This may suggest a fundamental difference between these enteric hepatitis viruses in mechanisms of protective immunity that favor acute resolution versus persistence of infection.

As with HAV, HEV causes a noncytopathic infection in cultured cells (Shukla et al. 2011; Okamoto 2013) and replication of the virus is robust during the prodromal phase of infection, well before the onset of hepatitis. It is therefore also likely that liver injury in acute hepatitis $\mathrm{E}$ is also immune mediated, but involvement of $\mathrm{T}$ cells or other innate cytotoxic populations has not yet been investigated. Apparent differences in the severity of liver disease in HEV gt 1 and gt2 versus gt 3 and gt 4 infections, and the severity of HEV gt 1 infections in the late stages of pregnancy, has also highlighted the need for a better understanding of adaptive cellular immunity and the potential of the response to cause liver pathology.

Most early studies of T-cell immunity elicited by HEV gt1 viruses involved analysis of responses in peripheral blood against recombinant ORF2 capsid protein. Using the IFN- $\gamma$ ELISpot assay as a readout, an elevated frequency of circulating ORF-2-specific T cells was reported in subjects with acute and resolved infections when compared to uninfected controls with no known history of exposure to HEV (Wu et al. 2008; Husain et al. 2011; Tripathy et al. 2012). The ELISpot assay does not provide insight into the relative contribution of $\mathrm{CD}^{+}$ versus $\mathrm{CD} 8^{+} \mathrm{T}$ cells to IFN- $\gamma$ production. Use of the recombinant ORF2 protein almost certainly favored detection of the $\mathrm{CD} 4^{+}$helper subset because large proteins are processed inefficiently (if at all) for class I presentation to $\mathrm{CD} 8^{+}$ $\mathrm{T}$ cells. An IFN- $\gamma$ ELISpot response against a recombinant ORF2 protein was also described in six chimpanzees after recovery from experimental challenge with an HEV gt1 isolate (Shata et al. 2007). An attempt to detect IFN- $\gamma$ production by ORF2-stimulated $\mathrm{CD}^{+}$and $\mathrm{CD} 8^{+} \mathrm{T}$ cells from patients with sporadic acute icteric hepatitis $\mathrm{E}$ using flow cytometry failed for rea- sons that are not clear (Srivastava et al. 2007) Thus, the T-cell response to HEV gt1 viruses remains very poorly characterized despite the enormous number of symptomatic infections it causes globally, and the potential for catastrophic infection outcome in pregnant women and others who develop fulminant hepatitis.

More detailed analyses of T-cell immunity were undertaken in humans with acute, convalescent, and chronic HEV gt 3 infections. Collectively, these studies assessed $\mathrm{T}$-cell responses after stimulation of PBMCs with overlapping peptides sets spanning the ORF1, ORF2, and ORF3 domains, an approach that facilitates detection of $\mathrm{CD}^{+}$and $\mathrm{CD}^{+}{ }^{+} \mathrm{T}$-cell responses $(\mathrm{Su}-$ neetha et al. 2012; Brown et al. 2016; Gisa et al. 2016; Al-Ayoubi et al. 2018). Common findings from these studies can be summarized as follows:

1. Typical acute resolving HEV infection. $\mathrm{CD} 4{ }^{+}$ and $\mathrm{CD}^{+}{ }^{+} \mathrm{T}$ cells targeting all three HEV open reading are present in the peripheral blood during the acute phase of HEV infection, as judged by their capacity to proliferate and/or produce cytokines like MIP-1 $\beta$, IFN$\gamma$, and TNF- $\alpha$ (Fig. 2A) (Suneetha et al. 2012; Brown et al. 2016; Gisa et al. 2016; Al-Ayoubi et al. 2018). HEV-specific $T$ cells are also present in the peripheral blood of convalescent subjects (Suneetha et al. 2012; Brown et al. 2016; Gisa et al. 2016; Al-Ayoubi et al. 2018), but frequencies decline rapidly in the months after resolution of infection (Brown et al. 2016). Frequencies were much higher in the 12 months immediately after infection when compared with time points later than 1 year (Brown et al. 2016). Epitopes targeted by $\mathrm{CD} 4^{+}$and $\mathrm{CD} 8^{+} \mathrm{T}$ cells were mapped to more conserved domains of the HEV proteome (Brown et al. 2016). Indeed, some T-cell populations elicited by HEV gt3 infection recognized epitopes that were conserved in HEV gt1 viruses, indicating priming of cross-genotype immunity.

2. HEV in immune compromised patients. As noted above, HEV can persist when immunity is profoundly impaired and the number of circulating $\mathrm{CD}^{+}$and $\mathrm{CD}^{+} \mathrm{T}$ cells is signifi- 
cantly reduced (Kamar et al. 2008, 2011). When compared with uncomplicated acute hepatitis $\mathrm{E}$, virus-specific $\mathrm{CD} 4^{+}$and $\mathrm{CD}^{+} \mathrm{T}$ cells are present at very low frequency and are generally difficult to detect in patients with chronic hepatitis (Suneetha et al. 2012; Brown et al. 2016). It is noteworthy that $\mathrm{CD}^{+} \mathrm{T}$ cells from chronically infected subjects regained antiviral effector functions when cultured in the presence of antibodies against the PD-1 coinhibitory receptor (Suneetha et al. 2012). Inhibitory PD-1 signaling is a major driver of T-cell exhaustion in other chronic virus infections. This result suggests that loss of T-cell proliferation and effector functions in chronic hepatitis E occurs by a similar process to that described for other persistent viruses like hepatitis $\mathrm{C}$ virus (HCV) (Suneetha et al. 2012). One key question is whether T-cell immunity recovers after successful treatment of chronic hepatitis $\mathrm{E}$ with ribavirin or reduced immune suppression. Longitudinal analysis of chronically infected patients undergoing therapy did reveal expansion of HEV-specific T cells in blood within 4 weeks of viral clearance (Suneetha et al. 2012). In a second study, a strong IFN$\gamma$ ELISpot response by ORF2-stimulatedPBMC was also associated with successful control of chronic HEV infection after antiviral therapy or reduction of immune suppression (Abravanel et al. 2016). How long these $T$ cells persist in blood after termination of infection has not been determined. T-cell immunity was not detected in transplant patients studied approximately 2 years after cure of chronic hepatitis E, suggesting that long-term memory may not develop or that frequencies drop below the threshold for detection in blood (Brown et al. 2016). Finally, improvement in $\mathrm{CD}^{+} \mathrm{T}$-cell numbers and immune function after initiation of antiretroviral therapy in patients coinfected with HIV and HEV might be expected to facilitate resolution of the HEV infection. However, in at least some individuals, HEV may continue to persist despite apparent reconstitution of immune function (Ingiliz et al. 2016). This observation suggests that chronic HEV infec- tion established during immune suppression can cause a pervasive and perhaps permanent block on generation of anti-HEV antiviral responses that persists well after general conditions of immune suppression are reversed.

To date, there is very limited direct evidence that $\mathrm{CD}^{+}$and/or $\mathrm{CD} 8^{+} \mathrm{T}$ cells suppress HEV replication or cause immunopathology in the liver. It is reasonable to speculate that noncytotoxic T-cell control of HEV replication is common because most infections, especially those caused by gt 3 and gt 4 viruses, are clinically inapparent. Replication of the virus in cell culture is sensitive to treatment with $\mathrm{T}$-cell-produced cytokines like IFN- $\gamma$ (Todt et al. 2016) and TNF- $\alpha$ (Behrendt et al. 2017). Cytokine-mediated inhibition of HEV replication is supported by one compelling case report of severe exacerbation of chronic infection during treatment with a TNF- $\alpha$ inhibitor for psoriatic arthritis (Behrendt et al. 2017). Interestingly, HEV-specific T-cell immunity was detected in this patient during treatment with the TNF- $\alpha$ inhibitor, but virus replication increased sharply until treatment with the inhibitor was discontinued and ribavirin was administered to control the infection (Behrendt et al. 2017).

\section{SUMMARY AND FUTURE DIRECTIONS: THE NEED TO UPDATE MODELS OF ADAPTIVE IMMUNITY IN ENTERIC HEPATITIS VIRUS INFECTIONS}

The importance of adaptive immune responses to control of enteric hepatitis virus infections has been considered largely settled for many years. For example, the model of T-cell immunity that emerged from the first studies of acute HAV infection approximately 30 years ago is still widely accepted. It was proposed that control of acute HAV infection requires a virus-specific $\mathrm{CD}^{+}$cytotoxic $\mathrm{T}$-cell response that clears infected hepatocytes and causes acute hepatitis as collateral damage (Maier et al. 1988; Fleischer et al. 1990; Vallbracht and Fleischer 1992). The same model of $\mathrm{CD}^{+}{ }^{+} \mathrm{T}$-cell-mediated virus control and liver injury has been adopted for HEV, given the very similar timing and clinical profile 
of acute infection for both enteric hepatitis viruses. It is important to emphasize, however, that a temporal kinetic relationship between expansion of functional antiviral $\mathrm{CD}^{+} \mathrm{T}$ cells, control of viremia or fecal shedding, and acute hepatitis remains to be established for HAV or HEV infection.

Remarkably few studies of either virus have been undertaken since the emergence of powerful technologies that permit direct visualization of antiviral $\mathrm{CD} 4^{+}$and $\mathrm{CD} 8^{+} \mathrm{T}$ cells, assessment of antiviral functions, and differentiation into effector and memory populations. The value in continuing studies of adaptive immunity against $\mathrm{HAV}$ and HEV is highlighted by recent studies that argue against a requirement for $\mathrm{CD}^{+} \mathrm{T}$ cells in termination of infection or as a cause of acute hepatitis. As described in this review, $\mathrm{CD}^{+} \mathrm{T}$ cells did not acquire effector functions until after viremia was substantially controlled in one contemporary study of acute HAV infection in chimpanzees (Zhou et al. 2012). This unexpected finding suggested that functional cytotoxic $\mathrm{CD}^{+} \mathrm{T}$ cells are not necessarily required to control acute HAV infection, and perhaps, by extension, HEV infection although this remains to be determined. A link between HLA class I restricted $\mathrm{CD} 8^{+}$cytotoxic T-cell activity and acute hepatitis has also not yet been confirmed. Compelling new studies indicate that hepatocellular injury may instead be multifactorial, involving cytotoxic activity by innate or bystander T cells (Choi et al. 2018b; Kim et al. 2018) and activation of certain type I IFN signaling pathways (Hirai-Yuki et al. 2016a).

With regard to humoral immune responses, the capacity of neutralizing antibodies generated by natural infection or vaccination to provide apparent sterilizing immunity against HAV or HEV is well established. This protective immunity appears to be lifelong in the case of HAV infection. Reinfection with HEV has been documented in some individuals after resolution of a primary infection or even after vaccination, but how commonly antibody-mediated protection fails and under what conditions remains to be determined.

A key unresolved question is whether antibodies contribute to control of acute HAV or
HEV infection. As noted above, T-cell immunity has been considered of paramount importance in resolution of infection but a role for antibodies cannot yet be excluded. As noted above, two observations provide some support for this concept. First, at least for HAV, active or passive immunization within 14 days of virus exposure provides direct evidence for antibody-mediated inhibition of virus replication and tempering of acute hepatitis. Second, initial suppression of HAV or HEV replication during acute infection occurs at roughly the same time as seroconversion. The recent finding that HAV and HEV particles circulating in blood have a quasi-envelope is of significance when considering how and where virus is neutralized by antibodies (Feng et al. 2013; Yin et al. 2016). This form of the virus is almost certainly responsible for spread of both HAV and HEV between hepatocytes after infection is established. Because neutralization is now thought to occur after degradation of the quasi-envelope of $\mathrm{HEV}$ and $\mathrm{HAV}$ particles within the endolysosome, a role for the early pentameric IgM antibodies in containing initial spread of the virus seems doubtful. A key unresolved question is whether antiviral IgG antibodies, which arise later in infection and neutralize HAV and HEV particles after removal of the quasi-envelope in the endolysosome, accelerate termination of viremia or fecal shedding.

With these studies, new models of that explain how HAV and HEV infections are controlled by antibodies and $\mathrm{T}$ cells, and why the severity of liver disease is often so variable, have begun to emerge. Further efforts to sort out unresolved details of adaptive immunity against the enteric hepatitis viruses is of importance given the large number of infections that still occur globally each year, and the substantial burden of liver disease that they cause. HAV and $\mathrm{HEV}$ are also of importance as they are examples of small RNA viruses that are successfully controlled by intrahepatic immune responses. As noted above, certain HEV genotypes do persist in individuals with compromised immunity, but HAV does not for reasons that are poorly understood. A resurgence in interest and priority for research into adaptive immune responses against $\mathrm{HAV}$ and $\mathrm{HEV}$ could provide a much 
better general understanding of how virus infections are contained in the unique environment of the liver, and why host defenses sometimes fail during infections with viruses like $\mathrm{HBV}$ and $\mathrm{HCV}$ that have a propensity to persist.

\section{REFERENCES}

${ }^{*}$ Reference is also in this collection.

Abravanel F, Barrague H, Dorr G, Saune K, Peron JM, Alric L, Kamar N, Izopet J, Champagne E. 2016. Conventional and innate lymphocytes response at the acute phase of HEV infection in transplanted patients. J Infect 72: $723-$ 730.

* Aggarwal R, Goel A. 2018. Natural history, clinical manifestations, and pathogenesis of hepatitis E virus genotype 1 and 2 infections. Cold Spring Harb Perspect Med doi: 10.1101/cshperspect.a032136.

Al-Ayoubi J, Behrendt P, Bremer B, Suneetha PV, Gisa A, Rinker F, Manns MP, Cornberg M, Wedemeyer H, Kraft ARM. 2018. Hepatitis E virus ORF 1 induces proliferative and functional T-cell responses in patients with ongoing and resolved hepatitis E. Liver Int 38: 266-277.

Balayan MS, Andjaparidze AG, Savinskaya SS, Ketiladze ES, Braginsky DM, Savinov AP, Poleschuk VF. 1983. Evidence for a virus in non-A, non-B hepatitis transmitted via the fecal-oral route. Intervirology 20: 23-31.

Behrendt P, Luth S, Dammermann W, Drave S, Brown RJ, Todt D, Schnoor U, Steinmann E, Wedemeyer H, Pischke S, et al. 2017. Exacerbation of hepatitis E virus infection during anti-TNF $\alpha$ treatment. Joint Bone Spine 84: 217219.

Bendall R, Ellis V, Ijaz S, Thurairajah P, Dalton HR. 2008. Serological response to hepatitis E virus genotype 3 infection: IgG quantitation, avidity, and IgM response. J Med Virol 80: 95-101.

Bradley D, Andjaparidze A, Cook EH Jr, McCaustland K, Balayan M, Stetler H, Velazquez O, Robertson B, Humphrey C, Kane M, et al. 1988. Aetiological agent of enterically transmitted non-A, non-B hepatitis. J Gen Virol 69: 731-738.

Brown A, Halliday JS, Swadling L, Madden RG, Bendall R, Hunter JG, Maggs J, Simmonds P, Smith DB, Vine L, et al. 2016. Characterization of the specificity, functionality, and durability of host T-cell responses against the fulllength hepatitis E virus. Hepatology 64: 1934-1950.

Bryan JP, Tsarev SA, Iqbal M, Ticehurst J, Emerson S, Ahmed A, Duncan J, Rafiqui AR, Malik IA, Purcell RH, et al. 1994. Epidemic hepatitis E in Pakistan: Patterns of serologic response and evidence that antibody to hepatitis $\mathrm{E}$ virus protects against disease. J Infect Dis 170: 517-521.

Cai W, Tang ZM, Wen GP, Wang SL, Ji WF, Yang M, Ying D, Zheng ZZ, Xia NS. 2016. A high-throughput neutralizing assay for antibodies and sera against hepatitis E virus. Sci Rep 6: 25141.

Chandra NS, Sharma A, Malhotra B, Rai RR. 2010. Dynamics of HEV viremia, fecal shedding and its relationship with transaminases and antibody response in patients with sporadic acute hepatitis E. Virol J 7: 213.
Chapuy-Regaud S, Dubois M, Plisson-Chastang C, Bonnefois T, Lhomme S, Bertrand-Michel J, You B, Simoneau S, Gleizes PE, Flan B, et al. 2017. Characterization of the lipid envelope of exosome encapsulated HEV particles protected from the immune response. Biochimie 141: 70-79.

Chau KH, Dawson GJ, Bile KM, Magnius LO, Sjogren MH, Mushahwar IK. 1993. Detection of IgA class antibody to hepatitis E virus in serum samples from patients with hepatitis E virus infection. J Med Virol 40: 334-338.

Chauhan A, Jameel S, Dilawari JB, Chawla YK, Kaur U, Ganguly NK. 1993. Hepatitis E virus transmission to a volunteer. Lancet 341: 149-150.

Choi YS, Lee J, Lee HW, Chang DY, Sung PS, Jung MK, Park JY, Kim JK, Lee JI, Park H, et al. 2015. Liver injury in acute hepatitis A is associated with decreased frequency of regulatory T cells caused by Fas-mediated apoptosis. Gut 64: 1303-1313.

Choi M, Hofmann J, Kohler A, Wang B, Bock CT, Schott E, Reinke P, Nickel P. 2018a. Prevalence and clinical correlates of chronic hepatitis $\mathrm{E}$ infection in german renal transplant recipients with elevated liver enzymes. Transplant Direct 4: e341.

Choi YS, Jung MK, Lee J, Choi SJ, Choi SH, Lee HW, Lee JJ, Kim HJ, Ahn SH, Lee DH, et al. 2018b. Tumor necrosis factor-producing T-regulatory cells are associated with severe liver injury in patients with acute hepatitis A. Gastroenterology 154: 1047-1060.

Clayson ET, Myint KS, Snitbhan R, Vaughn DW, Innis BL, Chan L, Cheung P, Shrestha MP. 1995. Viremia, fecal shedding, and IgM and IgG responses in patients with hepatitis E. J Infect Dis 172: 927-933.

Cobden I, James OF. 1986. A biphasic illness associated with acute hepatitis A virus infection. J Hepatol 2: 19-23.

Conrad ME, Lemon SM. 1987. Prevention of endemic icteric viral hepatitis by administration of immune serum gamma globulin. J Infect Dis 156: 56-63.

Counihan NA, Anderson DA. 2016. Specific IgA enhances the transcytosis and excretion of hepatitis A virus. Sci Rep 6: 21855.

Daemer RJ, Feinstone SM, Gust ID, Purcell RH. 1981. Propagation of human hepatitis A virus in African green monkey kidney cell culture: Primary isolation and serial passage. Infect Immun 32: 388-393.

Dalton HR, Bendall RP, Keane FE, Tedder RS, Ijaz S. 2009. Persistent carriage of hepatitis E virus in patients with HIV infection. N Engl J Med 361: 1025-1027.

Das A, Hirai-Yuki A, Gonzalez-Lopez O, Rhein B, MollerTank S, Brouillette R, Hensley L, Misumi I, Lovell W, Cullen JM, et al. 2017. TIM1 (HAVCR1) is not essential for cellular entry of either quasi-enveloped or naked hepatitis A virions. MBio 8: e00969.

D'Hondt E, Purcell RH, Emerson SU, Wong DC, Shapiro M, Govindarajan S. 1995. Efficacy of an inactivated hepatitis A vaccine in pre- and postexposure conditions in marmosets. J Infect Dis 171: S40-S43.

Dotzauer A, Gebhardt U, Bieback K, Gottke U, Kracke A, Mages J, Lemon SM, Vallbracht A. 2000. Hepatitis A virus-specific immunoglobulin A mediates infection of hepatocytes with hepatitis A virus via the asialoglycoprotein receptor. J Virol 74: 10950-10957. 
C.M. Walker

Dotzauer A, Brenner M, Gebhardt U, Vallbracht A. 2005 IgA-coated particles of hepatitis A virus are translocalized antivectorially from the apical to the basolateral site of polarized epithelial cells via the polymeric immunoglobulin receptor. J Gen Virol 86: 2747-2751.

Dotzauer A, Heitmann A, Laue T, Kraemer L, Schwabe K, Paulmann D, Flehmig B, Vallbracht A. 2012. The role of immunoglobulin A in prolonged and relapsing hepatitis A virus infections. J Gen Virol 93: 754-760.

Drake ME, Ward C, Stokes J Jr, Henle W, Medairy GC Mangold F, Henle G. 1952. Studies on the agent of infectious hepatitis. III: The effect of skin tests for infectious hepatitis on the incidence of the disease in a closed institution. J Exp Med 95: 231-239.

Emerson SU, Clemente-Casares P, Moiduddin N, Arankalle VA, Torian U, Purcell RH. 2006. Putative neutralization epitopes and broad cross-genotype neutralization of hepatitis $\mathrm{E}$ virus confirmed by a quantitative cell-culture assay. J Gen Virol 87: 697-704

* Feinstone SM. 2018. History of the discovery of hepatitis A virus. Cold Spring Harb Perspect Med doi: 10.1101/ cshperspect.a031740.

Feinstone SM, Kapikian AZ, Purceli RH. 1973. Hepatitis A: Detection by immune electron microscopy of a viruslike antigen associated with acute illness. Science 182: 10261028 .

Feng Z, Hensley L, McKnight KL, Hu F, Madden V, Ping L, Jeong SH, Walker C, Lanford RE, Lemon SM. 2013. A pathogenic picornavirus acquires an envelope by hijacking cellular membranes. Nature 496: 367-371.

Feng Z, Li Y, McKnight KL, Hensley L, Lanford RE, Walker CM, Lemon SM. 2015. Human pDCs preferentially sense enveloped hepatitis A virions. J Clin Invest 125: 169-176.

Flehmig B, Zahn J, Vallbracht A. 1984. Levels of neutralizing and binding antibodies to hepatitis-A virus after onset of icterus: A comparison. J Infect Dis 150: 461.

Fleischer B, Vallbracht A. 1991. Demonstration of virus-specific cytotoxic T lymphocytes in liver tissue in hepatitis A-A model for immunopathological reactions. Behring Inst Mitt 89: 226-230.

Fleischer B, Fleischer S, Maier K, Wiedmann KH, Sacher M, Thaler H, Vallbracht A. 1990. Clonal analysis of infiltrating $\mathrm{T}$ lymphocytes in liver tissue in viral hepatitis $\mathrm{A}$. Immunology 69: 14-19.

Frosner GG, Deinhardt F, Scheid R, Gauss-Muller V, Holmes N, Messelberger V, Siegl G, Alexander JJ. 1979. Propagation of human hepatitis A virus in a hepatoma cell line. Infection 7: 303-305.

Gardinali NR, Guimaraes JR, Melgaco JG, Kevorkian YB, Bottino FO, Vieira YR, da Silva AC, Pinto DP, da Fonseca LB, Vilhena LS, et al. 2017. Cynomolgus monkeys are successfully and persistently infected with hepatitis E virus genotype 3 (HEV-3) after long-term immunosuppressive therapy. PLoS ONE 12: e0174070.

Gauss-Muller V, Frosner GG, Deinhardt F. 1981. Propagation of hepatitis A virus in human embryo fibroblasts. $J$ Med Virol 7: 233-239.

Gellis SS, Stokes J, Brother GM, Hall WM, Gilmore HR Beyer E. 1945. The use of immune serum globulin (gamma globulin) in infectious (epidemic) hepatitis in the Mediterranean theater of operations. I: Studies on pro- phylaxis in two epidemics of infectious hepatitis. $J \mathrm{Am}$ Med Assoc 128: 1062-1063.

Gisa A, Suneetha PV, Behrendt P, Pischke S, Bremer B, Falk CS, Manns MP, Cornberg M, Wedemeyer H, Kraft AR. 2016. Cross-genotype-specific T-cell responses in acute hepatitis E virus (HEV) infection. J Viral Hepat 23: 305-315.

Glikson M, Galun E, Oren R, Tur-Kaspa R, Shouval D. 1992. Relapsing hepatitis A. Review of 14 cases and literature survey. Medicine (Baltimore) 71: 14-23.

Green MS, Dotan K. 1988. Efficacy of immune serum globulin in an outbreak of hepatitis A virus infection in adults. J Infect 17: 265-270.

Havens WP Jr, Marck RE. 1946. The leukocytic response of patients with experimentally induced infectious hepatitis. Am J Med Sci 212: 129-138.

Havens WP, Paul JR. 1945. Prevention of infectious hepatitis with gamma globulin. J Am Med Assoc 129: 270-272.

Henle G, Drake M, Henle W, Stokes J Jr. 1950a. A skin test for infectious hepatitis. Proc Soc Exp Biol Med 73: 603605.

Henle W, Harris S, Henle G, Harris TN, Drake ME, Mangold F, Stokes J Jr. 1950b. Studies on the agent of infectious hepatitis; propagation of the agent in tissue culture and in the embryonated hen's egg. J Exp Med 92: 271-281.

Hirai-Yuki A, Hensley L, McGivern DR, Gonzalez-Lopez O, Das A, Feng H, Sun L, Wilson JE, Hu F, Feng Z, et al. 2016a. MAVS-dependent host species range and pathogenicity of human hepatitis A virus. Science 353: 15411545.

Hirai-Yuki A, Hensley L, Whitmire JK, Lemon SM. 2016b. Biliary secretion of quasi-enveloped human hepatitis A virus. MBio 7: $\mathrm{e} 01998$

* Hirai-Yuki A, Whitmire JK, Joyce M, Tyrrell DL, Lemon SM. 2018. Murine models of hepatitis A virus infection. Cold Spring Harb Perspect Med doi: 10.1101/cshperspect. a031674.

Hong S, Lee HW, Chang DY, You S, Kim J, Park JY, Ahn SH, Yong D, Han KH, Yoo OJ, et al. 2013. Antibody-secreting cells with a phenotype of Ki- $67^{\text {low }}, \mathrm{CD} 138^{\text {high }}, \mathrm{CD} 31^{\text {high }}$, and $\mathrm{CD} 38^{\text {high }}$ secrete nonspecific IgM during primary hepatitis A virus infection. J Immunol 191: 127-134.

Huang W, Zhang H, Harrison TJ, Lang S, Huang G, Wang Y. 2008. Cross-protection of hepatitis $\mathrm{E}$ virus genotypes 1 and 4 in rhesus macaques. J Med Virol 80: 824-832.

Huang S, Zhang X, Jiang H, Yan Q, Ai X, Wang Y, Cai J, Jiang L, Wu T, Wang Z, et al. 2010. Profile of acute infectious markers in sporadic hepatitis E. PLoS ONE 5: e13560.

Hughes JV, Stanton LW, Tomassini JE, Long WJ, Scolnick EM. 1984. Neutralizing monoclonal antibodies to hepatitis A virus: Partial localization of a neutralizing antigenic site. J Virol 52: 465-473.

Husain MM, Aggarwal R, Kumar D, Jameel S, Naik S. 2011. Effector T cells immune reactivity among patients with acute hepatitis E. J Viral Hepat 18: e603-608.

Ingiliz P, Mayr C, Obermeier M, Herbst H, Polywka S, Pischke S. 2016. Persisting hepatitis E virus infection leading to liver cirrhosis despite recovery of the immune system in an HIV-infected patient. Clin Res Hepatol Gastroenterol 40: e23-e25. 
* Jacobsen KH. 2018. Globalization and the changing epidemiology of hepatitis A virus. Cold Spring Harb Perspect Med doi: 10.1101/cshperspect.a031716.

Jacobson IM, Nath BJ, Dienstag JL. 1985. Relapsing viral hepatitis type A. J Med Virol 16: 163-169.

Jego G, Palucka AK, Blanck JP, Chalouni C, Pascual V, Banchereau J. 2003. Plasmacytoid dendritic cells induce plasma cell differentiation through type I interferon and interleukin 6. Immunity 19: 225-234.

Jia XY, Summers DF, Ehrenfeld E. 1992. Host antibody response to viral structural and nonstructural proteins after hepatitis A virus infection. J Infect Dis 165: 273-280.

Joshi YK, Babu S, Sarin S, Tandon BN, Gandhi BM, Chaturvedi VC. 1985. Immunoprophylaxis of epidemic nonA non-B hepatitis. Indian J Med Res 81: 18-19.

Kamar N, Selves J, Mansuy JM, Ouezzani L, Peron JM, Guitard J, Cointault O, Esposito L, Abravanel F, Danjoux M, et al. 2008. Hepatitis E virus and chronic hepatitis in organ-transplant recipients. $N$ Engl J Med 358: 811-817.

Kamar N, Garrouste C, Haagsma EB, Garrigue V, Pischke S, Chauvet C, Dumortier J, Cannesson A, Cassuto-Viguier E, Thervet E, et al. 2011. Factors associated with chronic hepatitis in patients with hepatitis $\mathrm{E}$ virus infection who have received solid organ transplants. Gastroenterology 140: 1481-1489.

Kamar N, Izopet J, Dalton HR. 2013. Chronic hepatitis E virus infection and treatment. J Clin Exp Hepatol 3: 134140.

Khuroo MS, Dar MY. 1992. Hepatitis E: Evidence for person-to-person transmission and inability of low dose immune serum globulin from an Indian source to prevent it. Indian J Gastroenterol 11: 113-116.

Khuroo MS, Kamili S, Dar MY, Moecklii R, Jameel S. 1993. Hepatitis E and long-term antibody status. Lancet 341: 1355.

Kim HY, Eyheramonho MB, Pichavant M, Gonzalez Cambaceres C, Matangkasombut P, Cervio G, Kuperman S, Moreiro R, Konduru K, Manangeeswaran M, et al. 2011. A polymorphism in TIM1 is associated with susceptibility to severe hepatitis A virus infection in humans. J Clin Invest 121: 1111-1118.

Kim J, Chang DY, Lee HW, Lee H, Kim JH, Sung PS, Kim KH, Hong SH, Kang W, Lee J, et al. 2018. Innate-like cytotoxic function of bystander-activated $\mathrm{CD} 8^{+} \mathrm{T}$ cells is associated with liver injury in acute hepatitis A. Immunity 48: 161-173.

Kojima H, Shibayama T, Sato A, Suzuki S, Ichida F, Hamada C. 1981. Propagation of human hepatitis A virus in conventional cell lines. J Med Virol 7: 273-286.

Krain LJ, Nelson KE, Labrique AB. 2014. Host immune status and response to hepatitis E virus infection. Clin Microbiol Rev 27: 139-165.

Kurane I, Binn LN, Bancroft WH, Ennis FA. 1985. Human lymphocyte responses to hepatitis A virus-infected cells: Interferon production and lysis of infected cells. J Immunol 135: 2140-2144.

Lanford RE, Feng Z, Chavez D, Guerra B, Brasky KM, Zhou Y, Yamane D, Perelson AS, Walker CM, Lemon SM. 2011 Acute hepatitis A virus infection is associated with a limited type I interferon response and persistence of intrahepatic viral RNA. Proc Natl Acad Sci 108: 11223-11228.
Legrand-Abravanel F, Kamar N, Sandres-Saune K, Garrouste C, Dubois M, Mansuy JM, Muscari F, Sallusto F, Rostaing L, Izopet J. 2010. Characteristics of autochthonous hepatitis $\mathrm{E}$ virus infection in solid-organ transplant recipients in France. J Infect Dis 202: 835-844.

Lemon SM, Binn LN. 1983. Serum neutralizing antibody response to hepatitis A virus. J Infect Dis 148: 1033-1039.

Lemon SM, Binn LN, Marchwicki R, Murphy PC, Ping LH, Jansen RW, Asher LV, Stapleton JT, Taylor DG, LeDuc JW. 1990. In vivo replication and reversion to wild type of a neutralization-resistant antigenic variant of hepatitis A virus. J Infect Dis 161: 7-13.

Lemon SM, Murphy PC, Provost PJ, Chalikonda I, Davide JP, Schofield TL, Nalin DR, Lewis JA. 1997. Immunoprecipitation and virus neutralization assays demonstrate qualitative differences between protective antibody responses to inactivated hepatitis A vaccine and passive immunization with immune globulin. J Infect Dis 176: 9-19.

Lemon SM, Ott JJ, Van Damme P, Shouval D. 2017. Type A viral hepatitis: A summary and update on the molecular virology, epidemiology, pathogenesis and prevention. J Hepatol.

Locarnini SA, Coulepis AG, Kaldor J, Gust ID. 1980. Coproantibodies in hepatitis A: Detection by enzyme-linked immunosorbent assay and immune electron microscopy. J Clin Microbiol 11: 710-716.

Maier K, Gabriel P, Koscielniak E, Stierhof YD, Wiedmann KH, Flehmig B, Vallbracht A. 1988. Human $\gamma$ interferon production by cytotoxic $T$ lymphocytes sensitized during hepatitis A virus infection. J Virol 62: 3756-3763.

Manangeeswaran M, Jacques J, Tami C, Konduru K, Amharref N, Perrella O, Casasnovas JM, Umetsu DT, Dekruyff RH, Freeman GJ, et al. 2012. Binding of hepatitis A virus to its cellular receptor 1 inhibits T-regulatory cell functions in humans. Gastroenterology 142: 15161525.e3.

Moal V, Motte A, Kaba M, Gerolami R, Berland Y, Colson P. 2013. Hepatitis E virus serological testing in kidney transplant recipients with elevated liver enzymes in 2007-2011 in southeastern France. Diagn Microbiol Infect Dis 76: 116-118.

Moller-Tank S, Maury W. 2014. Phosphatidylserine receptors: Enhancers of enveloped virus entry and infection. Virology 468-470: 565-580.

Montpellier C, Wychowski C, Sayed IM, Meunier JC, Saliou JM, Ankavay M, Bull A, Pillez A, Abravanel F, Helle F, et al. 2018. Hepatitis E virus lifecycle and identification of 3 forms of the ORF2 capsid protein. Gastroenterology 154: 211-223.e8.

Nagashima S, Takahashi M, Kobayashi T, Tanggis, Nishizawa T, Nishiyama T, Primadharsini PP, Okamoto $\mathrm{H}$. 2017. Characterization of the quasi-enveloped hepatitis E virus particles released by the cellular exosomal pathway. J Virol 91: e00822.

Okamoto H. 2013. Culture systems for hepatitis E virus. J Gastroenterol 48: 147-158.

Pas SD, de Man RA, Mulders C, Balk AH, van Hal PT, Weimar W, Koopmans MP, Osterhaus AD, van der Eijk AA. 2012. Hepatitis E virus infection among solid organ transplant recipients, the Netherlands. Emerg Infect Dis 18: $869-872$. 
C.M. Walker

Perez-Sautu U, Costafreda MI, Cayla J, Tortajada C, Lite J, Bosch A, Pinto RM. 2011. Hepatitis a virus vaccine escape variants and potential new serotype emergence. Emerg Infect Dis 17: 734-737.

Perrella A, Vitiello L, Atripaldi L, Sbreglia C, Grattacaso S, Bellopede P, Patarino T, Morelli G, Altamura S, Racioppi $\mathrm{L}$, et al. 2008. Impaired function of $\mathrm{CD} 4^{+} / \mathrm{CD} 25^{+} \mathrm{T}$ regulatory lymphocytes characterizes the self-limited hepatitis A virus infection. J Gastroenterol Hepatol 23: e105e110.

Ping LH, Lemon SM. 1992. Antigenic structure of human hepatitis A virus defined by analysis of escape mutants selected against murine monoclonal antibodies. J Virol 66: 2208-2216.

Ping LH, Jansen RW, Stapleton JT, Cohen JI, Lemon SM. 1988. Identification of an immunodominant antigenic site involving the capsid protein VP3 of hepatitis A virus. Proc Natl Acad Sci 85: 8281-8285.

Purcell RH, D'Hondt E, Bradbury R, Emerson SU, Govindarajan S, Binn L. 1992. Inactivated hepatitis A vaccine: Active and passive immunoprophylaxis in chimpanzees. Vaccine 10: S148-151.

Purcell RH, Nguyen H, Shapiro M, Engle RE, Govindarajan S, Blackwelder WC, Wong DC, Prieels JP, Emerson SU. 2003. Pre-clinical immunogenicity and efficacy trial of a recombinant hepatitis E vaccine. Vaccine 21: 2607-2615.

Reyes GR, Purdy MA, Kim JP, Luk KC, Young LM, Fry KE, Bradley DW. 1990. Isolation of a cDNA from the virus responsible for enterically transmitted non-A, non-B hepatitis. Science 247: 1335-1339.

Robertson BH, D'Hondt EH, Spelbring J, Tian H, Krawczynski K, Margolis HS. 1994. Effect of postexposure vaccination in a chimpanzee model of hepatitis A virus infection. J Med Virol 43: 249-251.

Sarkar S, Rivera EM, Engle RE, Nguyen HT, Schechterly CA, Alter HJ, Liang TJ, Purcell RH, Hoofnagle JH, Ghany MG. 2015. An epidemiologic investigation of a case of acute hepatitis E. J Clin Microbiol 53: 3547-3552.

Schiff ER. 1992. Atypical clinical manifestations of hepatitis A. Vaccine 10: S18-S20.

Schulte I, Hitziger T, Giugliano S, Timm J, Gold H, Heinemann FM, Khudyakov Y, Strasser M, Konig C, Castermans E, et al. 2011. Characterization of $\mathrm{CD}^{+} \mathrm{T}$-cell response in acute and resolved hepatitis A virus infection. J Hepatol 54: 201-208.

Seriwatana J, Shrestha MP, Scott RM, Tsarev SA, Vaughn DW, Myint KS, Innis BL. 2002. Clinical and epidemiological relevance of quantitating hepatitis E virus-specific immunoglobulin M. Clin Diagn Lab Immunol 9: 10721078

Servant-Delmas A, Abravanel F, Lefrere JJ, Lionnet F, Hamon C, Izopet J, Laperche S. 2016. New insights into the natural history of hepatitis $\mathrm{E}$ virus infection through a longitudinal study of multitransfused immunocompetent patients in France. J Viral Hepat 23: 569-575.

Shata MT, Barrett A, Shire NJ, Abdelwahab SF, Sobhy M, Daef E, El-Kamary SS, Hashem M, Engle RE, Purcell RH et al. 2007. Characterization of hepatitis E-specific cellmediated immune response using IFN- $\gamma$ ELISPOT assay. J Immunol Methods 328: 152-161.
* Shin E-C, Jeong S-H. 2018. Natural history, clinical manifestations, and pathogenesis of hepatitis A. Cold Spring Harb Perspect Med doi: 10.1101/cshperspect.a031708.

Shukla P, Nguyen HT, Torian U, Engle RE, Faulk K, Dalton HR, Bendall RP, Keane FE, Purcell RH, Emerson SU. 2011. Cross-species infections of cultured cells by hepatitis $\mathrm{E}$ virus and discovery of an infectious virus-host recombinant. Proc Natl Acad Sci 108: 2438-2443.

Sikuler E, Keynan A, Hanuka N, Friedman MG, Sarov I. 1983. Detection and persistence of specific IgA antibodies in serum of patients with hepatitis A by capture radioimmunoassay. J Med Virol 11: 287-294.

Sjogren MH, Tanno H, Fay O, Sileoni S, Cohen BD, Burke DS, Feighny RJ. 1987. Hepatitis A virus in stool during clinical relapse. Ann Intern Med 106: 221-226.

Sonder GJ, van Steenbergen JE, Bovee LP, Peerbooms PG, Coutinho RA, van den Hoek A. 2004. Hepatitis A virus immunity and seroconversion among contacts of acute hepatitis A patients in Amsterdam, 1996-2000: An evaluation of current prevention policy. Am J Public Health 94: $1620-1626$.

Srivastava R, Aggarwal R, Jameel S, Puri P, Gupta VK, Ramesh VS, Bhatia S, Naik S. 2007. Cellular immune responses in acute hepatitis $\mathrm{E}$ virus infection to the viral open reading frame 2 protein. Viral Immunol 20: 56-65.

Stapleton JT. 1995. Host immune response to hepatitis A virus. J Infect Dis 171: S9-S14.

Stapleton JT, Lemon SM. 1987. Neutralization escape mutants define a dominant immunogenic neutralization site on hepatitis A virus. J Virol 61: 491-498.

Stapleton JT, Lange DK, LeDuc JW, Binn LN, Jansen RW, Lemon SM. 1991. The role of secretory immunity in hepatitis A virus infection. J Infect Dis 163: 7-11.

Stewart DR, Morris TS, Purcell RH, Emerson SU. 1997. Detection of antibodies to the nonstructural $3 \mathrm{C}$ proteinase of hepatitis A virus. J Infect Dis 176: 593-601.

Stokes J, Neefe JR. 1945. The prevention and attenuation of infectious hepatitis by $\gamma$ globulin. J Am Med Assoc 127: 144-145.

Stokes J Jr, Farquhar JA, Drake ME, Capps RB, Ward CS Jr, Kitts AW. 1951. Infectious hepatitis; length of protection by immune serum globulin (gamma globulin) during epidemics. J Am Med Assoc 147: 714-719.

Suneetha PV, Pischke S, Schlaphoff V, Grabowski J, Fytili P, Gronert A, Bremer B, Markova A, Jaroszewicz J, Bara C, et al. 2012. Hepatitis E virus (HEV)-specific T-cell responses are associated with control of HEV infection. Hepatology 55: 695-708.

Takahashi M, Tanaka T, Takahashi H, Hoshino Y, Nagashima S, Jirintai, Mizuo H, Yazaki Y, Takagi T, Azuma M, et al. 2010. Hepatitis E virus (HEV) strains in serum samples can replicate efficiently in cultured cells despite the coexistence of HEV antibodies: Characterization of HEV virions in blood circulation. J Clin Microbiol 48: 1112-1125.

Tanaka T, Takahashi M, Kusano E, Okamoto H. 2007. Development and evaluation of an efficient cell-culture system for Hepatitis E virus. J Gen Virol 88: 903-911.

Tanaka T, Takahashi M, Takahashi H, Ichiyama K, Hoshino Y, Nagashima S, Mizuo H, Okamoto H. 2009. Development and characterization of a genotype 4 hepatitis $\mathrm{E}$ 
virus cell culture system using a HE-JF5/15F strain recovered from a fulminant hepatitis patient. J Clin Microbiol 47: 1906-1910.

Todt D, Francois C, Anggakusuma, Behrendt P, Engelmann M, Knegendorf L, Vieyres G, Wedemeyer H, Hartmann R, Pietschmann T, et al. 2016. Antiviral activities of different interferon types and subtypes against hepatitis E virus replication. Antimicrob Agents Chemother 60: 21322139.

Tripathy AS, Das R, Rathod SB, Arankalle VA. 2012. Cytokine profiles, CTL response and $\mathrm{T}$ cell frequencies in the peripheral blood of acute patients and individuals recovered from hepatitis E infection. PLoS ONE 7: e31822.

Tsarev SA, Tsareva TS, Emerson SU, Govindarajan S, Shapiro M, Gerin JL, Purcell RH. 1994. Successful passive and active immunization of cynomolgus monkeys against hepatitis E. Proc Natl Acad Sci 91: 10198-10202.

Tsarev SA, Tsareva TS, Emerson SU, Govindarajan S, Shapiro M, Gerin JL, Purcell RH. 1997. Recombinant vaccine against hepatitis E: Dose response and protection against heterologous challenge. Vaccine 15: 1834-1838.

Vallbracht A, Fleischer B. 1992. Immune pathogenesis of hepatitis A. Arch Virol Suppl 4: 3-4.

Vallbracht A, Gabriel P, Maier K, Hartmann F, Steinhardt HJ, Muller C, Wolf A, Manncke KH, Flehmig B. 1986. Cell-mediated cytotoxicity in hepatitis A virus infection. Hepatology 6: 1308-1314.

Vallbracht A, Maier K, Stierhof YD, Wiedmann KH, Flehmig B, Fleischer B. 1989. Liver-derived cytotoxic T cells in hepatitis A virus infection. J Infect Dis 160: 209-217.

Victor JC, Monto AS, Surdina TY, Suleimenova SZ, Vaughan G, Nainan OV, Favorov MO, Margolis HS, Bell BP. 2007. Hepatitis A vaccine versus immune globulin for postexposure prophylaxis. N Engl J Med 357: 16851694.

Vollmer T, Diekmann J, Eberhardt M, Knabbe C, Dreier J. 2016. Hepatitis E in blood donors: Investigation of the natural course of asymptomatic infection, Germany, 2011. Euro Surveill 21: 30332.

Wang CH, Tschen SY, Heinricy U, Weber M, Flehmig B. 1996. Immune response to hepatitis A virus capsid proteins after infection. J Clin Microbiol 34: 707-713.

Wang X, Ren J, Gao Q, Hu Z, Sun Y, Li X, Rowlands DJ, Yin W, Wang J, Stuart DI, et al. 2015. Hepatitis A virus and the origins of picornaviruses. Nature 517: 85-88.

Wang W, Xu L, Brandsma JH, Wang Y, Hakim MS, Zhou X, Yin Y, Fuhler GM, van der Laan LJ, van der Woude CJ, et al. 2016. Convergent transcription of interferon-stimulated genes by TNF- $\alpha$ and IFN- $\alpha$ augments antiviral activity against HCV and HEV. Sci Rep 6: 25482.

Wang X, Zhu L, Dang M, Hu Z, Gao Q, Yuan S, Sun Y, Zhang B, Ren J, Kotecha A, et al. 2017. Potent neutralization of hepatitis A virus reveals a receptor mimic mechanism and the receptor recognition site. Proc Natl Acad Sci 114: 770775 .

Whelan J, Sonder GJ, Bovee L, Speksnijder A, van den Hoek A. 2013. Evaluation of hepatitis A vaccine in post-exposure prophylaxis, The Netherlands, 2004-2012. PLoS ONE 8: e78914.

Wu T, Zhang J, Su ZJ, Liu JJ, Wu XL, Wu XL, Lin CX, Ou SH, Yan Q, Shih JW, et al. 2008. Specific cellular immune response in hepatitis E patients. Intervirology 51: 322327.

Yin X, Ambardekar C, Lu Y, Feng Z. 2016. Distinct entry mechanisms for nonenveloped and quasi-enveloped hepatitis E viruses. J Virol 90: 4232-4242.

Yin XD, Y, Lhomme S, Tang Z, Walker C, Xia N, Zheng Z, Feng Z. 2018. Origin, antigenicity, and function of a secreted form of ORF2 in hepatitis E virus infection. Proc Natl Acad Sci doi: 10.1073/pnas.1721345115.

Yu C, Engle RE, Bryan JP, Emerson SU, Purcell RH. 2003. Detection of immunoglobulin $\mathrm{M}$ antibodies to hepatitis $\mathrm{E}$ virus by class capture enzyme immunoassay. Clin Diagn Lab Immunol 10: 579-586.

Zahn J, Vallbracht A, Flehmig B. 1984. Hepatitis A-virus in cell culture. V. Neutralizing antibodies against hepatitis A-virus. Med Microbiol Immunol 173: 9-17.

Zhang JZ, Im SW, Lau SH, Chau TN, Lai ST, Ng SP, Peiris M, Tse C, Ng TK, Ng MH. 2002. Occurrence of hepatitis E virus IgM, low avidity IgG serum antibodies, and viremia in sporadic cases of non- $\mathrm{A},-\mathrm{B}$, and $-\mathrm{C}$ acute hepatitis. J Med Virol 66: 40-48.

Zhang J, Li SW, Wu T, Zhao Q, Ng MH, Xia NS. 2012. Hepatitis E virus: Neutralizing sites, diagnosis, and protective immunity. Rev Med Virol 22: 339-349.

Zhang J, Shih JW, Xia NS. 2015. Long-term efficacy of a hepatitis E vaccine. N Engl J Med 372: 2265-2266.

Zhou Y, Callendret B, Xu D, Brasky KM, Feng Z, Hensley LL, Guedj J, Perelson AS, Lemon SM, Lanford RE, et al. 2012. Dominance of the $\mathrm{CD} 4^{+} \mathrm{T}$ helper cell response during acute resolving hepatitis A virus infection. J Exp Med 209: 1481-1492. 


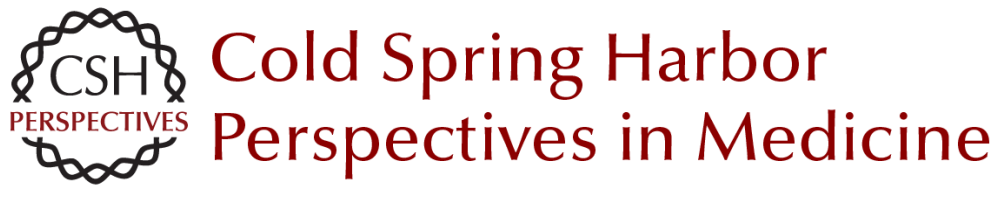

\section{Adaptive Immune Responses in Hepatitis A Virus and Hepatitis E Virus Infections}

Christopher M. Walker

Cold Spring Harb Perspect Med 2019; doi: 10.1101/cshperspect.a033472 originally published online May 29, 2018

\section{Subject Collection Enteric Hepatitis Viruses}

Hepatitis A Virus Genome Organization and

Replication Strategy

Kevin L. McKnight and Stanley M. Lemon

Adaptive Immune Responses in Hepatitis A Virus and Hepatitis E Virus Infections Christopher M. Walker

Small Animal Models of Hepatitis E Virus Infection Tian-Cheng Li and Takaji Wakita

Acute and Persistent Hepatitis E Virus Genotype 3 and 4 Infection: Clinical Features, Pathogenesis, and Treatment

Nassim Kamar and Sven Pischke

Epidemiology of Genotype 1 and 2 Hepatitis E

Virus Infections

Kenrad E. Nelson, Alain B. Labrique and Brittany L. Kmush

History of the Discovery of Hepatitis A Virus Stephen M. Feinstone

Epidemiology and Transmission of Hepatitis A Virus and Hepatitis E Virus Infections in the United States

Megan G. Hofmeister, Monique A. Foster and Eyasu H. Teshale

Stem Cell-Derived Culture Models of Hepatitis E

Virus Infection

Viet Loan Dao Thi, Xianfang Wu and Charles M. Rice
Evolutionary Origins of Enteric Hepatitis Viruses Anna-Lena Sander, Victor Max Corman, Alexander N. Lukashev, et al.

Enterically Transmitted Non-A, Non-B Hepatitis and the Discovery of Hepatitis E Virus Stanley M. Lemon and Christopher M. Walker

Natural History, Clinical Manifestations, and

Pathogenesis of Hepatitis E Virus Genotype 1 and

2 Infections

Rakesh Aggarwal and Amit Goel

Hepatitis A Virus and Hepatitis E Virus: Emerging and Re-Emerging Enterically Transmitted

Hepatitis Viruses

Stanley M. Lemon and Christopher M. Walker

Hepatitis A Virus Capsid Structure

David I. Stuart, Jingshan Ren, Xiangxi Wang, et al.

Comparative Pathology of Hepatitis A Virus and

Hepatitis E Virus Infection John M. Cullen and Stanley M. Lemon

Innate Immunity to Enteric Hepatitis Viruses Zongdi Feng and Stanley M. Lemon

Nonhuman Primate Models of Hepatitis A Virus and Hepatitis E Virus Infections

Robert E. Lanford, Christopher M. Walker and

Stanley M. Lemon

For additional articles in this collection, see http://perspectivesinmedicine.cshlp.org/cgi/collection/ 